\title{
THE PROTECTION OF HUMAN RIGHTS IN DOMESTIC LAW: LEARNING LESSONS FROM THE EUROPEAN COURT OF HUMAN RIGHTS.
}

\begin{abstract}
Steve Foster
ABSTRACT

The Human Rights Act 1998 came into force in October 2000, its purpose to allow victims of alleged violations of rights contained in the European Convention on Human Rights (1950) to pursue a remedy in the domestic courts. Thus, central to the Act's purpose is to enable the access of the rights and remedies already provided by the machinery of the European Convention, subject only to those provisions of the Act which seek to retain the principle of parliamentary sovereignty. The purpose of this article is to study the case law of the European Court of Human Rights in relation to cases brought against the United Kingdom in order to examine the United Kingdom's record under the Convention and, hopefully, of identifying common themes of human rights violations for which the United Kingdom has consistently been held responsible, and for which they may remain vulnerable to challenge in the future. At this stage it will be submitted that the European Convention has exposed the limitations of human rights protection in domestic law, and that on many occasions both the courts and Parliament have failed to adopt the necessary jurisprudence of the European Court in their respective roles. Finally, in the light of that evidence the article will examine the provisions of the Human Rights Act 1998 in order to assess the likely impact of that Act on the protection of rights and liberties in the United Kingdom.
\end{abstract}

\section{INTRODUCTION}

The decisions of the European Court of Human Rights concerning cases involving the United Kingdom continues to draw attention to possible defects within domestic law relating to the protection of fundamental rights. Cases concerning the ban of homosexuals in the armed forces, ${ }^{1}$ the fairness of criminal proceedings applied to young offenders, ${ }^{2}$ and the release of mandatory life sentence prisoners $^{3}$ have fuelled this debate and the government was forced to introduce reforms in some of these areas. ${ }^{4}$ In

* School of International Studies and Law, Coventry University. I am grateful to my colleague Mark Ryan, and to Kevin Bampton at Derby University for their constructive comments on earlier drafts of this article. All errors remain mine.

1 Smith and Grady v United Kingdom (2000) 29 EHRR 493, and Lustig-Prean and Beckett v United Kingdom (2000) 29 EHRR 548.

$2 V$ and $T \mathrm{v}$ United Kingdom (2000) 30 EHRR 121.

3 Recently, the Grand Chamber of the European Court of Human Rights decided in Stafford $\mathrm{v}$ United Kingdom, The Times, 28 May 2002, that the power of the Home Secretary to determine the release of mandatory life-sentence prisoners was in violation of art 5 .

4 In response to the European Court's ruling in A $v$ United Kingdom the government issued a consultation document entitled Protecting Children, Supporting Parents, 
addition to those high profile cases, the European Court continues to find against the government in areas including freedom of speech and protest, ${ }^{5}$ private life $^{6}$ and various aspects of due process ${ }^{7}$ and liberty of the person. These cases, along with many others involving the United Kingdom, will be presented as typical examples of human rights violations in the United Kingdom and will be referred to in an attempt to identify what has been an apparent gulf in the method of human rights protection between domestic law and of the European Convention. Whilst it is hoped that this discrepancy will be addressed now that the Human Rights Act 1998 is in operation, this article suggests that such a transformation will not happen simply because the courts are armed with European principles and case law, and that the success of the Act will depend primarily on whether those responsible for making and adjudicating upon the law are prepared to embrace the true spirit of fundamental human rights.

As examined below, many judges have insisted that that the British method of securing rights and liberties is comparable and compatible with the system contained under the European Convention. In order to decide whether the domestic system of rights protection has ever, or is capable of matching that of the Convention it is thus necessary to make a study of the traditional method of protecting human rights in domestic law. With no constitutional or higher law as such, and no formal bill of rights, individuals have had to

inviting public response. Shortly after the decision in $V$ and $T \mathrm{v}$ United Kingdom, the Lord Chief Justice issued a Practice Direction: Practice Direction (Crown Court: trial of children and young persons) with directions reflecting the European Court's decision.

5 Steel v United Kingdom (1999) 28 EHRR 603, and Hashman and Harrap v United Kingdom (2000) 30 EHRR 241.

6 See McLeod v United Kingdom (1999) 27 EHRR 493, Khan v United Kingdom (2001) 31 EHRR 45 and $P G$ and JH v United Kingdom, The Times, 19 October 2001, Foxley v United Kingdom (2000) 8 BHRC 571), ADT v United Kingdom (2000) 9 BHRC 112, and TP and KM v United Kingdom, (2002) 34 EHRR 2, and most recently the judgments in Goodwin $\mathrm{v}$ United Kingdom and I $\mathrm{v}$ United Kingdom, The Times, 12 July 2002. See also the recent judgment of the European Court in Hatton v United Kingdom, (2002) 34 EHRR 1, where the Court held that the applicants' right to family and private life had been violated by night flights to and from Heathrow airport. The government has appealed to the Grand Chamber under art 43 of the Convention.

7 See, for example, Rowe and Davis v United Kingdom (2000) 30 EHRR 1, Jasper v United Kingdom and Fitt v United Kingdom (2000) 30 EHRR 1; McGonnell v United Kingdom (2000) 30 EHRR 289; Condron v United Kingdom (2001) 31 EHRR 1, Stanford v United Kingdom (The Times, 12 May, 2000), Mageee v United Kingdom (2000) 8 BHRC 646; Averill v United Kingdom (2000) 8 BHRC 430; Kingsley v United Kingdom (The Times, January 9 2001), Howarth v United Kingdom 9 BHRC 253 and Atlan v United Kingdom, (2002) 34 EHRR 33. See also the recent judgment in Morris v United Kingdom (2002) 34 EHRR 52, decision of the European Court 26 February 2002, on the incompatibility of the court martial system with art 6, and Ezeh and Connors v United Kingdom, judgment of the European Court 15 July 2002, The Times, 30 July 2002, on the denial of legal representation to prisoners at prison disciplinary hearings.

8 See, for example, Jordan v United Kingdom (2001) 11 BHRC 1; Caballero v United Kingdom (2000) 30 EHRR 643; Oldham v United Kingdom (2001) 31 EHRR 34, SBC v United Kingdom (2002) 34 EHRR 21, Hirst v United Kingdom, The Times, August 32001 and O'Hara v United Kingdom (2002) 34 EHRR 32. 
rely on the common law, statute and public opinion to safeguard their civil liberties. ${ }^{9}$ In the absence of a tangible bill of rights, the enjoyment of civil liberties has been governed by the principle of residual liberty: we are free to do anything that the law does not forbid. ${ }^{10}$ In addition to this laudable, yet precarious state of affairs, the rights of individuals are bolstered by statutory provisions which either provide specific protection of civil liberties, ${ }^{11}$ or which temper the restriction of civil liberty which has otherwise been authorised by the law. ${ }^{12}$ More importantly the courts have taken it upon themselves to protect individual liberty from unlawful and arbitrary interference $^{13}$ and have developed a human rights jurisprudence which assumes that Parliament does not intend to interfere with certain fundamental rights, ${ }^{14}$ and which subjects any prima facie lawful interference to a more intense judicial review. ${ }^{15}$ More specifically, domestic law embraced, to a limited extent, the rights and the case law of the European Convention on

9 For a general account of the domestic situation see H Fenwick, Civil Liberties and Human Rights (2002) and D Feldman, Civil Liberties and Human Rights in England and Wales (2002). For a critical analysis of recent government legislation and human rights protection in domestic law, see H Fenwick, Civil Rights: New Labour, Freedom and the Human Rights Act (2000).

10 See McGarry VC in Malone v Metropolitan Police Commissioner [1979] Ch 344, at 366E. For a criticism of this method, and of the decision in Malone, see Sedley, Freedom Law and Justice (1999), pp10-12.

11 In addition to the Human Rights Act 1998 various legislation provides protection against discrimination: the Sex Discrimination Act 1975, the Race Relations Act 1976 and the Disability Discrimination Act 1988. Freedom of speech is protected is by a variety of specific provisions: see s1 Public Meetings Act 1908, s43 Education (No 2) Act 1986, and The Public Interest Disclosure Act 1998 and the Freedom of Information Act 2000.

12 For example, the Police and Criminal Evidence Act 1984 contains a variety of safeguards against arbitrary use of the police powers contained in the Act. See also s4 of the Obscene Publications Act 1959, which provides a public good defence to a charge of publishing obscene material.

13 See, for example, Webb v Chief Constable of Merseyside Police; Porter and another v Chief Constable of Merseyside Police [2000] 1 All ER 29, where the Court of Appeal held that the courts would not countenance the expropriation of property by a public authority without clear statutory authority.

14 On access to the courts, see Chester v Bateson [1920] 1KB 829; Raymond v Honey [1983] 1 AC 1; $R$ v Secretary of State for the Home Department Ex parte $O$ 'Brien and Simms [1999] 3 All ER 400, $R$ v Secretary of State for the Home Department Ex parte Saleem [2001] 1WLR 443 and $R \mathrm{v}$ Secretary of State for the Home Department, Ex parte Daly, [2001] 2 WLR 1622. See also the recent House of Lords' decision in $R$ (on the application of Morgan Grenfell and Co Ltd) v Special Commissioner [2002] 2 WLR 1299 on the protection of documents covered by legal professional privilege. See in particular Lord Irvine, "Activism and Restraint: Human Rights and the Interpretative Process" [1999] EHRLR 350 and J Jowell, "Beyond the Rule of Law: Towards Constitutional Judicial Review"[2000] PL 671.

15 See $R$ v Ministry of Defence Ex parte Smith [1996] 1 All ER 257; $R$ v Secretary of State for the Home Department Ex parte Bugdaycay [1986] 1 All ER 458; and $R \mathrm{~V}$ Lord Saville of Newdigate Ex parte A (The Times, 22 June 1999), affirmed in the Court of Appeal [1999] 4 All ER 860. 
Human Rights (1950). ${ }^{16}$ Thus, it was permissible for the courts to use the Convention in cases of statutory ambiguity, ${ }^{17}$ or to develop uncertain common law, ${ }^{18}$ and the courts eventually, after some initial reticence, ${ }^{19}$ referred to the case law of the European Court of Human Rights when determining issues under domestic law. ${ }^{20}$

Despite the existence and application of these constitutional techniques, the domestic arrangements for securing civil liberties continued to come under fire. ${ }^{21}$ As explained below, the United Kingdom government has been repeatedly brought before the European Commission and Court of Human Rights to defend, mostly unsuccessfully, domestic laws and practices that have violated the Convention rights of individuals within its jurisdiction. Indeed, despite the wider aim of the Human Rights Act 1998 to introduce a culture of human rights protection into domestic law, the Act has been primarily introduced to meet the government's responsibilities under the Convention and so to offer a human rights protection equivalent to the one provided by the European Convention. ${ }^{22}$ If this primary aim is to be realised, therefore, the domestic authorities must pay heed to the essential principles enshrined in the European Convention and, in particular, to the jurisprudence of the European Court of Human Rights. An analysis of the case law of the European Court which has involved the United Kingdom government should, therefore, reveal not only the deficiencies of our domestic system of protecting civil liberties, but should also provide the relevant domestic authorities with an insight into the philosophy of a human rights protection which they must embrace with the passing of the Human Rights Act 1998. In particular, it is suggested that the cases reveal inevitable deficiencies of the traditional system, allowing us to draw some conclusions as to how the domestic authorities must proceed if the aims and spirit of the Human Rights Act are to be realised.

${ }^{16}$ Even before October 2000, the courts had begun to consider some cases in the light of the Human Rights Act 1998. See $R$ v DPP, Ex parte Kebilene [1999] 4 All ER 801.

$17 R \mathrm{v}$ Secretary of State for the Home Department Ex parte Brind [1991] AC 696.

18 Attorney General v Guardian Newspapers (No 2) [1990] 1 AC 109; $R$ v Chief Metropolitan Magistrate ex parte Choudhury [1991] 1 QB 429; and Derbyshire CC v Times Newspapers [1993] AC 534.

19 See $R \vee$ Morrissey and Staines (The Times, May 1, 1997, and the High Court decision in Camelot $\mathrm{v}$ Centaur Communications (The Times, July 17, 1997)

20 See the Court of Appeal decision in Camelot $\mathrm{v}$ Centaur Communications [1998] 1 All ER 251. See also the decision of the High Court in $R$ v DPP Ex parte Kebeline (The Times, March 31, 1999).

21 See R Gordon and Wilmott-Smith (eds), Human Rights in the United Kingdom (1996); M Zander, A Bill of Rights? (1997); and R Singh, The Future of Human Rights in the United Kingdom (1997) chaps 1 and 2.

22 The Human Rights Act resulted from the Labour Party consultation paper: Bringing Rights Home: Labour's Plans to incorporate the ECHR into UK law. See J Straw and P Boateng, "Bringing Rights Home: Labour's plans to incorporate the European Convention on Human Rights into UK law" [1997] EHRLR 71. 


\section{THE UNITED KINGDOM BEFORE THE EUROPEAN COURT OF HUMAN RIGHTS}

The cases that we will study in this section of the article fall into two broad categories: those where there was held to be a violation because the human right in question was not recognised in domestic law, and those where the right, although recognised, was given insufficient weight or recognition by the law or its application. By grouping the cases in this way, it is hoped that many of the cases that have been decided by the European Court can be explained in relation to particular characteristics and deficiencies of the traditional method of rights protection.

For example, in the first category we will look at cases where the domestic law has failed to accommodate certain human rights, or has failed to extend certain human rights to particular persons. This will, hopefully, highlight both the failure of the common law to recognise certain rights, as well as exposing the consequences of the lack of a formal bill of rights. Within this second broad category we will also look at a host of cases where the United Kingdom government was held accountable for what, it is submitted, are the natural consequences of its human rights arrangements: the interference of liberty via the granting of excessive executive discretion, and the violation of the rights of minority and other vulnerable groups. In certain cases, there will be an evident overlap between the two broad categories, and the divisions within the second category. For example, the cases involving prisoners is studied under both broad categories and is put forward as evidence of the abuse of minority rights and the excessive granting of executive discretion. Nevertheless, it is hoped that by examining the cases within these categories that it will be possible to identify and highlight several characteristics and failings of the domestic law's system of rights protection, and of providing a possible solution to the United Kingdom's worrying record under the Convention.

\section{Where The Convention Right Is Not Recognised In Domestic Law}

There have been a number of cases where the European Court has held that the United Kingdom was in violation of the Convention as a direct consequence of the failure of the domestic legal system to recognise a particular Convention right. The clearest example of this type of case is Malone v United Kingdom..$^{23}$ Here, the domestic courts were unable to provide the applicant with a remedy for what was a clear violation of his right to private life and correspondence. ${ }^{24}$ Thus, inevitably, the European Court held that such a violation could not be justified within the restrictions permitted by Article 8(2) because the restrictions were both administrative and secretive and not contained in the law so as to be in accordance with law.' ${ }^{25}$ Dealing with the issue of whether there had been a violation of Article

23 (1985) 7 EHRR 14. The applicant's telephone had been tapped during police investigations.

24 Malone v Metropolitan Police Commissioner, see $\mathrm{n} 10$ above.

25 To be in accordance with or prescribed by law for the purposes of the Convention a restriction must emanate from a recognised legal source and must be sufficiently accessible and clear. See Sunday Times v United Kingdom (1979) 2 EHRR 245. 
8 of the Convention, the European Court agreed with the Commission's findings that the existence of practices that establish a system for affecting such secret surveillance constituted a violation of Malone's rights under Article $8 .{ }^{26}$ Having established such, the Court then went on to consider whether the restriction on Malone's rights were in accordance with law as required by Article 8(2). It concluded that it could not be said with any reasonable certainty what elements of the powers to intercept are incorporated in legal rules and what elements remain within the discretion of the executive. To that extent, the minimum degree of legal protection to which citizens are entitled under the rule of law in a democratic society was lacking. ${ }^{27}$

As a result of the European Court's judgement, Parliament was forced to pass the Interception of Communications Act 1985, which at least put the practice of telephone tapping on a legal basis. ${ }^{28}$ However, the failure of Parliament to fully address the issue and to legislate for a general right of privacy led to further defeats for the government. Thus, in Halford $\mathrm{v}$ United Kingdom ${ }^{29}$ the European Court held that the right to private life and correspondence under Article 8 also applied to conversations held on the employer's premises. As the Interception to Communications Act 1985 did not cover the tapping of such conversations, the United Kingdom again fell foul of Article 8 of the Convention. More recently the European Court found a violation of Article 8 of the Convention when it held that the absence of domestic law warranting and regulating the use of covert listening devises constituted an interference with the applicant's right of private life. As the interference had been authorised via unpublished Home Office guidelines such interference were not, in the Court's opinion, in accordance with law' as required by Article 8 (2). ${ }^{30}$ These cases clearly illustrate a particular deficiency of the common law system of protecting human rights: a right which is not recognised at the domestic level is a right which is clearly protected in international law and consequently the government are held to account by the European Court without any consideration of whether the restrictions, had they been in legal form, were necessary in a democratic society for the purpose of achieving a legitimate social aim.

See H Mountfield, "The concept of a lawful interference with fundamental human rights", in Understanding Human Rights Principles (2001), p 5.

26 (1985) 7 EHRRR 14, at para 64. The previous decision in Klass v Federal Republic of Germany (1979) 2 EHRR 214 had established that telephone conversations were covered by the notions of private life and correspondence under Art 8.

27 Ibid, at para 79.

28 See now the Regulation of Investigatory Powers Act 2000.

29 (1997) 24 EHRR 523

30 Khan v United Kingdom (2001) 31 EHRR 45, and PG and JH v United Kingdom, The Times, October 212001 . For these reasons, the Court also found a breach of Art 13 of the Convention: the right of an individual to an effective remedy for breach of Convention rights. Covert surveillance is now covered by s 93 of the Police Act 1997. See also the admissibility decision in Govell v United Kingdom (Application No 27237/95), and the decision of the European Court in Arnott v United Kingdom, judgment of the European Court of Human Rights, November 7, 2000) and Armstrong v United Kingdom (judgment of the European Court of Human Rights, 15 July 2002, The Times, August 6 2002). 
This deficiency in our domestic arrangements was also apparent in the recent case involving the banning of homosexuals in the armed forces: Smith and Grady v United Kingdom; Lustig-Prean and Beckett v United Kingdom. ${ }^{31}$ This ban was challenged in the domestic courts ${ }^{32}$ on the grounds, inter alia, that it was in contravention of both Article 8 of the European Convention and EC Council Directive (EC) 76/207. Both the High Court and the Court of Appeal held that Article 8 of the Convention could not be used directly to challenge the ban and that the European directive did not cover discrimination on grounds of sexual orientation. ${ }^{33}$ This case highlights the lack of intensity in judicial review cases involving human rights issues and will be discussed in that context later in the article. However, with regard to our present discussions, the judicial review proceedings highlighted the failure of domestic law to recognise and protect the fundamental right of private life. The absence of a clear law of private life forced the courts to decide the case on traditional judicial review grounds. Although the domestic courts were sympathetic to the applicants' plight, they were powerless to find that the Ministry had acted in such a way as to permit the courts to interfere. Indeed, the allegations that the investigations conducted by military personnel into the sexual activities of the applicants constituted a violation of their private lives were not debated in the domestic proceedings. There being no general law of privacy, such allegations were not relevant and the courts were forced to concentrate on the rationality of continuing the ban, albeit in the light of the fact that the decision affected the fundamental rights of the applicants. ${ }^{34}$ Of course, when the case reached the European Court of Human Rights it found a clear violation of Article 8, in particular with regard to the manner in which the applicants' homosexuality had been investigated. Thus, the European Court found that the investigations conducted by the Ministry, and in particular the interviews of the applicants, were especially intrusive, and that in combination with the profound affect that their discharges had on the applicants' careers and prospects there had been an especially grave interference with their private lives..$^{35}$

Cases such as Malone and Smith are, of course, the clearest examples of the deficiencies of the traditional system, and a development of a coherent and complete law of privacy was perhaps the most glaring gap in our system of

31 See $n 1$ above.

$32 R$ v Ministry of Defence, Ex parte Smith [1995] 4 All ER 427, affirmed in the Court of Appeal: [1996] 1 All ER 257.

33 See Grant v South West-Trains [1998] ECR I-621. See now Macdonald v Ministry of Defence (2001) IRLR 431.

34 [1996] 1 All ER 257, Sir Thomas Bingham MR at 263e-264f. It is difficult to see which fundamental right the domestic courts were actually referring to in this case. Having rejected the arguments based on the EC Directive and the direct use of Art 8 of the European Convention, the only right the applicants would have would be a common law constitutional right. Unfortunately domestic law does not recognise the right of private life as such and thus the courts reference to human rights appears to be purely rhetorical.

35 Smith and Grady v United Kingdom, at para 89; Lustig-Prean and Beckett v United Kingdom, at para 64. In a separate judgment the European Court awarded each applicant $£ 19,000$ for pecuniary damage, representing especially grave violations of their Convention rights: Judgment of the European Court, 25 July 2000. 
human rights protection. ${ }^{36}$ Although many privacy interests were safeguarded under the traditional laws of trespass and confidentiality, the lack of a general right of private life led to gaps in that protection, where gross invasions of privacy remained unchecked. ${ }^{37}$ This, it is suggested, is the consequence of rights being protected within a remedy driven by legal rules, rather than human rights theory. ${ }^{38}$ Of equal concern are those cases, such as Smith, where the absence of a formally recognised right of privacy has resulted in the courts referring to a vague notion of private life in order to justify a more intense judicial supervision.

This failure to recognise Convention rights is again evident in cases where the particular right, although formally recognised in domestic law, is, for some reason of legal policy, effectively removed in particular circumstances. For example, the provision of legal immunity to certain bodies, capable of restricting individual human rights, was the subject of litigation in the case of Osman v United Kingdom. ${ }^{39}$ In this case the failure of domestic law to allow a plaintiff to sue the police in negligence resulted in a finding by the European Court that the United Kingdom was in violation of Article 6 of the Convention, which guarantees the right to a fair trial:

"... the application of the rule in this manner without further enquiry into the existence of competing public interest considerations only serves to confer a blanket immunity on the police for their actions and omissions. . . and amounts to an unjustifiable restriction on an applicant's right to have a determination on the merits of his or her claim against the police in deserving cases." ${ }^{40}$

36 See in general Michael, "Privacy", in McCrudden and Chambers, Individual Rights and the Law in Britain (OUP 1995) and Birks (ed), Privacy and Loyalty (Clarendon 1998). See also T Bingham, "Should there be a law to Protect Rights of Personal Privacy?" [1996] EHRLR 450.

37 See Kaye v Robertson [1991] FSR 62. For suggestions on how the domestic law could be used to develop protection of privacy interests, see G Phillipson and $\mathrm{H}$ Fenwick, "Breach of Confidence as a Privacy Remedy in the Human Rights Act Era" (2000) 63 MLR 660.

38 The absence of a right to privacy before the Human Rights Act 1998 was confirmed recently by the Court of Appeal in Secretary of State for the Home Department v Wainwright and another, The Times, January 4 2002, a case involving an act committed before the Act came into operation. Since the Act came into force the courts have begun to develop existing common law in line with the right to private life. See, for example, Douglas and others v Hello! Ltd [2001] 2 WLR 992 and Venables and Thompson v News Group Newspapers Ltd and others [2001] 1 All ER 908. See also A v B plc and another [2002] 2 All ER 545. See R Singh and J Strachan, "The Right to Privacy in English Law" [2002] EHRLR 129, and Wright J, Tort Law and Human Rights (Hart 2001), chapter 7.

39 (2000) 29 EHRR 245. See Wright J, Tort Law and Human Rights (Hart 2001), chapter 4, where the author analyses the domestic and European case law involved in this case.

$40 \mathrm{Ibid}$, at para 151. See also the decisions of the European Court in $Z \mathrm{v}$ United Kingdom (2002) 34 EHRR 3 and TP and KM v United Kingdom (2002) 34 EHRR 2. In those cases the Court held, inter alia, that art 6 was not violated by the striking out of the applicant's cases on public policy grounds, thus substantially limiting the impact of its decision in Osman. See Gearty, C 'Osman Unravels' (2000) 65 MLR, 87. However, the Court did find a violation of Art 13 of the 
In a similar group of cases the European Court have been called upon to adjudicate in cases involving persons whose rights have for some reason been excluded from the protection of domestic law. In this context the treatment of prisoners provides the clearest example. Until the late 1970's, the domestic courts were adamant that prison law and practice was not subject to judicial review. ${ }^{41}$ Thus, although prisoners had some private law rights, the domestic courts insisted that the public law decisions of prison authorities were not subject to judicial interference. This position resulted in a number of decisions of the European Court, which fundamentally altered the rights of prisoners, not only within the Convention itself, but also within domestic law. ${ }^{42}$

Cases before the European Court involving prisoners and other detainees, and other cases relating to claims made by homosexuals and transsexuals who have had their rights either removed or ignored by domestic law, highlight the deficiencies of an incomplete system of human rights protection. Either the system is not sophisticated enough to accommodate the specific claims of individuals - as evidenced, for example, by the lack of a law of privacy - or political or legal opinion has conspired against a group of individuals to give them little or no protection of their basic rights. These deficiencies have been highlighted by a number of European Court decisions, reminding the United Kingdom government that the rights laid out in the Convention are for all, and that it is not permissible to offer a sub-standard protection of such rights to particular persons or class of persons.

\section{Where Insufficient Weight Has Been Given To The Convention Right}

\section{i) The balancing of freedoms in general}

Many of the Convention rights are not absolute, but may be interfered with in certain situations, provided the interference satisfies the tests of legality and proportionality that are laid out in the Convention. In many cases, therefore, it is incumbent upon the domestic authorities to balance those Convention rights with either other Convention rights or other individual or group interests. ${ }^{43}$ Disputes will thus arise when an individual feels that the domestic law and practice have failed to give due weight to their rights, and have as a consequence failed to safeguard such rights against unnecessary and arbitrary interference. This section of the article looks at cases where the

Convention in that they failed to provide the applicants with an effective remedy with respect to violations of arts 3 and 8 of the Convention.

41 See Arbon v Anderson [1943] KB 252, and Becker v Home Office [1972] 2 QB 407. The position was altered following the decision in $R \mathrm{v}$ Hull Board of Visitors Ex parte St Germaine [1979] QB 425. Later decisions in Leech v Deputy Governor of Parkhurst [1988] 1 AC 533, and $R$ v Deputy Governor of Parkhurst Prison Ex parte Hague [1992] 1 AC 58 opened up all prison law decisions to judicial review.

42 In particular Golder v United Kingdom (1979-80) 1 EHRR 524 and Silver v United Kingdom (1983) 5 EHRR 347.

43 See A McHarg, "Reconciling Human Rights and Public Interest: Conceptual Problems and Doctrinal Uncertainty in the Jurisprudence of the European Court of Human Rights" (1999) 62 ML R 671. 
European Court has decided that the domestic authorities have quite simply got the balance wrong. Although this may be the consequence of any appeal system, it is suggested that these defeats can be traced back to the deficiencies of our traditional system of rights protection, and more particularly to a failure of those authorities to appreciate the value of Convention rights.

This category of cases is, therefore, characterised by the failure of the domestic law, including the courts, to give adequate weight to a right, which although recognised in domestic law is not given sufficient legal or moral weight by those who enforce, or adjudicate upon the law. Consequently, the competing right or interest is given an elevated status that is inconsistent with the case law of the Convention. Although the courts are (generally) insistent that certain rights are constitutional, and thus should be protected from undue or arbitrary interference, ${ }^{44}$ the case law of the European Convention discussed below shows that in cases where a particular right is in conflict with other rights or other social policy that the domestic courts are paying insufficient attention to the claimed right. ${ }^{45}$ The disparity between the domestic principle of irrationality and the European Court's application of the doctrine of proportionality will be highlighted later in this article, but a study of one or two examples at this stage may serve to illustrate the frailty of human rights in disputes involving the balancing of competing interests.

For example, in Ex parte Brind ${ }^{46}$ the House of Lords unanimously upheld the legality and rationality of the Home Secretary's decision to use section 29 (3) of the Broadcasting Act 1981 to place restrictions on the reporting of words spoken by or on behalf of certain terrorist organisations. Despite their Lordships' insistence that freedom of expression was of fundamental importance in domestic law, and that any interference would need to be justified by strong evidence, all three courts upheld restrictions which imposed a form of censorship on the broadcasting authorities and which extended to the speech of elected political representatives. The decision of the House of Lords is famous for its rejection both of the doctrine of proportionality and the direct use of (Article 10) of the European

44 See for example the comments made by Lord Bridge in $R \mathrm{v}$ Secretary of State for the Home Department Ex parte Brind [1991] AC 696, at 748H-749A where he stated that "... we are entitled to start from the premise that any restriction of the right of freedom of expression requires to be justified and nothing less than an important competing public interest will be sufficient to justify it." This principle was applied by the High Court when it was decided that the decision of the Health Secretary to hold the inquiry into the murder of patients by Harold Shipman in private was unlawful as being, inter alia, contrary to the principle of free speech: $R$ v Secretary of State for Health, Ex parte Wagstaff and another [2001] 1 WLR 292. See also $R$ (on the application of ProLife Alliance) $\vee$ British Broadcasting Corporation, [2002] 2 All ER 756.

45 This judicial attitude is highlighted in particular by cases such as $R \mathrm{v}$ Ministry of Defence, Ex parte Smith [1996] 1 All ER 257, $R$ v Secretary of State for the Home Department Ex parte Brind [1991] AC 696, and $R$ v Secretary of State for the Home Department, Ex parte McQuillan [1995] 3 All ER 400, all of which will be studied in this article. For a comprehensive account of how the domestic courts have used human rights law to resolve disputes see M Hunt, Using Human Rights Law in English Courts (1997).

46 Supra, n 43. 
Convention. Consequently the question was asked whether a reasonable Home Secretary, being aware of the importance of free speech and broadcasting, would have imposed such restrictions. Given that the Home Secretary received approval from Parliament for such actions, and that the Court was stressed that the decision was that of the Home Secretary and not of the court, it was not surprising that their Lordships felt that the Home Secretary's actions were consistent with domestic law, and indeed any test prescribed under treaties such as the European Convention.

Some of their Lordships' comments are worthy of note. In the House of Lords, Lord Lowry concluded that he could not see how 'the modest invasion of liberties (italics added) which has occurred in this case could fail to satisfy any of the criteria which have been suggested, including those criteria which, in point of law $\mathrm{I}$, in common with your Lordships, have found unacceptable." ${ }^{47}$ Also, Lord Bridge expressed his surprise that the restrictions did not go further: they did not restrict the matter that was to be broadcast and were viewed by his Lordship as a mere irritant to journalists. ${ }^{48}$ As will be illustrated below, these comments are inconsistent with the philosophy of the Convention and the European Court and will need to be revised once the courts are armed with increased supervisory powers. ${ }^{49}$

A further inadequacy of judicial supervision is highlighted in cases such as ex parte McQuillan. ${ }^{50}$ In this case the applicant had been made the subject of an exclusion order under section 5 of the Prevention of Terrorism (Temporary Provisions) Act 1989. He claimed that his and his family's life was in danger as long as they continued to live in Northern Ireland, and he challenged the decision on the basis, inter alia, that it was contrary to Articles 2 and 3 of the European Convention. In the High Court, Sedley J recognised that the right to life and the right not to be subject to inhuman treatment by executive action, were fundamental values of the common law and that it was the duty of the court to scrutinise administrative decisionmaking which infringed such rights to ensure that all relevant considerations

47 Ibid, p 764, E-F, italics added.

48 Ibid, at p 749, D-F, italics added. See also Lord Donaldson MR in the Court of Appeal: "If the directives are to be criticised at all, it must be on the basis that any use of the power will or may damage the reputation of the broadcasting authorities for total independence from the government of the day and that this price was not worth paying for so small an effect." [1990] 1 All ER 469 at p 482, a-b.

49 This view is not, it is submitted, rendered nugatory by the European Commission's decision to declare Brind's application inadmissible: Brind $\mathrm{v}$ United Kingdom, (1994) 77-A DR 42. At that stage the restrictions had been lifted and, in any case, the European Court would have approached the issue very differently from that of the domestic courts.

$50 R \mathrm{v}$ Secretary of State for the Home Department, Ex parte McQuillan [1995] 4 All ER 400. See also $R$ v Secretary of State for the Home Department, Ex parte Adams [1995] All ER 177. For the courts' general reluctance to look behind the Home Secretary's decisions in this context see $R \vee$ Secretary of State for the Home Department, Ex parte Cheblak [1991] 2 All ER 319, and $R$ v Secretary of State for the Home Department Ex parte Hosenball [1977] 3 All ER 452. Contrast the decision of the High Court in $R \mathrm{v}$ Secretary of State for the Home Department, ex Parte Louis Farrakhan, The Daily Telegraph, October 9, 2001, a post-Human Rights Act case, which is discussed later in the article but which was overturned by the Court of Appeal: [2002] 3WLR 481. 
had been taken into account. ${ }^{51}$ Nevertheless, his Lordship stated that authority dictated that where an executive decision affecting such rights was made in the interests of national security that was sufficient to preclude any enquiry into the rationality of the decision. Thus, the decision had to be accepted by the Court without further scrutiny. ${ }^{52}$

These two cases provide evidence of two related problems of judicial activity in the area of human rights protection. Either the courts are reluctant to apply the stringent tests applied by the European Court, or, more dangerously, fail to see the significance of a particular breach and thus the inadequacy of their traditional tools of supervision. Indeed, in cases such as Brind, the courts have convinced themselves that the traditional method is consistent with the standards laid down in the Convention, and that such decisions would stand up to the European Court's scrutiny. In the light of such judicial reticence, it is not surprising that the European Court has found United Kingdom law and practice to be deficient in cases where the law and the courts have sought to balance fundamental rights with other rights and social interests.

The case of Sunday Times v United Kingdom ${ }^{53}$ provides a prime example. In that case, the European Court found that the finding of The Sunday Times in contempt of court for publishing two articles which commented on the Thalidomide case at a time when some litigation relating to the incident was pending was an unjustified interference with the newspaper's, and the public's, right to freedom of expression under Article 10 of the Convention. In the domestic proceedings the courts had attempted to strike a balance between the right to a fair trial and the impartiality of judicial proceedings on the one hand, and freedom of expression on the other, but had concluded that the articles were still a real threat to the impartiality of the relevant proceedings. ${ }^{54}$ In assessing this judgment, the European Court stressed that Article 10 did not involve a balancing exercise, but instead guaranteed freedom of expression subject to specific and tightly drawn exceptions. ${ }^{55} \mathrm{In}$ the Court's opinion the thalidomide disaster was a matter of undisputed public concern: fundamental issues concerning protection against and compensation for injuries resulting from scientific developments were raised. ${ }^{56}$ This difference of emphasis, and the Court's stance on press freedom, and its duty to inform the public, led it to conclude that in the circumstances the contempt proceedings were neither necessary nor proportionate:

51 [1995] 4 All ER 400, at p 422, d-j.

52 Ibid, at $\mathrm{p} 423$, $\mathrm{f}-\mathrm{h}$.

53 (1979) 2 EHRR 245

54 Attorney General v Times Newspapers [1974] AC 273.

55 (1979) 2 EHRR, at paragraph 65. However, see the decision in Imutran Ltd $\mathrm{v}$ Uncaged Campaigns Ltd and another [2001] 2 All ER 386, in which Sir Andrew Morritt VC held that s 12(4) of the Human Rights Act 1998 did not place a duty on the court to place even greater weight on the importance of freedom of expression than it already did. This aspect of the decision seemed to be called into question by the Court of Appeal decision in A v B plc and another [2002] 2 All ER 545 .

56 Ibid, at para 66. 
"It is true that if the. . . article had appeared at the intended time, Distillers might have felt obliged to develop in public, and in advance of any trial, their arguments on the facts of the case; however, those facts did not cease to be a matter of public interest merely because they formed the background of pending litigation." 57

Cases such as Sunday Times provide clear evidence of the European Court's desire to protect freedom of expression and, in particular, press freedom. The Court have consistently held that such freedom is essential to both the rights contained in Article 10 and to the goals of a democratic society in general. ${ }^{58}$ For example in Lingens v Austria ${ }^{59}$ the European Court reminded itself that freedom of expression was one of the essential foundations of a democratic society and one of the basic conditions for its progress and for each individual's self-fulfilment. ${ }^{60}$ It also held that those principles were of particular importance as far as the press was concerned:

"Whilst the press must not overstep the bounds set, inter alia, for the protection of others", it is nevertheless incumbent on it to impart information and ideas on political issues just as on those in other areas of public interest. Not only does the press have the task of imparting such information and ideas; the public also has a right to receive them. ${ }^{61}$

In this respect the domestic courts have not been idle in responding to the acceptance of those principles of press freedom which the European Court have stressed lie at the heart of free speech in any democratic society. ${ }^{62}$ Thus in the law of defamation the House of Lords have held that it is not possible for democratically elected bodies to sue in defamation, their judgement being based on the idea that such would have a chilling effect on the discussion of democratic issues. ${ }^{63}$ Even though this allows individuals within such bodies to sue in defamation, in Reynolds ${ }^{64}$ the House of Lords have developed the

57 Ibid. See also Observer and Guardian v United Kingdom (1991) 14 EHRR 153 on the question of press freedom and prior restraint.

58 See in particular Sunday Times v United Kingdom (1979) 2 EHHR 245; Lingens v Austria (1986) 8 EHRR 407; Jersild v Denmark (1994) 19 EHRRR 1; and Oberschlick v Austria (1998) 25 EHRR 357. See also S Tierney, "Press Freedom and the Public Interest: The Developing Jurisprudence of the European Court of Human Rights" [1998] EHRLR 419.

59 Supra, n 58.

60 Lingens v Austria (1986) 8 EHRR 407, at para 41. See also Handyside v United Kingdom (1976) 1 EHRR 737, at para 49.

${ }^{61} \mathrm{Ibid}$, at para 41.

62 A good example of judicial support of press freedom can be seen in the Court of Appeal's judgment in Attorney-General v Punch Ltd and Another [2001] 2 All ER 655. Here the Court of Appeal held that for a third party to be bound by a court order forbidding disclosure of information if they knowingly defeated the purpose of the order; the publication of material specified in the injunction did not automatically constitute contempt.

63 Derbyshire County Council v Times Newspapers [1993] AC 534. Followed in Goldsmith v Bhoyral [1997] 4 All ER 268 and applied to democratically elected political parties.

64 Reynolds v Times Newspapers [1999] 4 All ER 609. See I Loveland, "A new legal landscape? Libel Law and Freedom of Political Expression in the United Kingdom" (2000) EHRLR 476. Also note the recent House of Lords' decision in 
defences of law of fair comment and qualified privilege so as to recognise, at least partially, the right of the press to comment on matters of public interest. ${ }^{65}$ Although the House of Lords in Reynolds did not go so far as to develop 'political information' as a generic category of information which would attract qualified privilege, and thus give the press the freedom that they enjoy in the United States, ${ }^{66}$ its judgement appears to sufficiently consistent with the case law of the European Court to ensure compatibility within article $10 .{ }^{67}$

In the area of press freedom and the disclosure of press sources, the case of Goodwin v United Kingdom, ${ }^{68}$ provides a very interesting illustration of the different perceptions of the domestic and European courts towards issues of press freedom. A journalist had been forced to disclose the identity of his source and had been held in contempt of court for refusing to do so. ${ }^{69}$ When the case was referred to the European Court it was held that the domestic proceedings amounted to a disproportionate interference with his rights under Article 10. In the Court's view the original injunctions, which had stopped the journalist from disclosing the relevant information, were sufficient to protect the rights of the owners of the information and thus any further restriction was not necessary in a democratic society, as required under Article 10(2). The Court paid particular attention to the need to protect press sources and the importance of such a right within the context of Article 10:

"Protection of journalistic sources is one of the basic conditions for press freedom. . Without such protection, sources may be deterred from assisting the press in informing the public on matters of public interest. ... Having regard to the importance of the protection of journalistic sources for press freedom in a democratic society and the potentially chilling effect an order of source disclosure has on the exercise of that freedom, such a measure cannot be compatible with Article $10 \ldots$ unless it is justified by an overriding requirement in the public interest" $" 70$

McCartan Turkington Breen v Times Newspapers Ltd [2000] 3 WLR 1670, where the House of Lords held that a press conference was a public meeting for the purposes of s7 of the Defamation (Northern Ireland) Act 1955, thus providing the press with a defence of qualified privilege to report such matters. See I Loveland, "Freedom of Political expression: who needs the Human Rights Act?" [2001] PL 233.

65 See Loutchansky v Times Newspapers Ltd (No 2) [2002] 1 All ER 652.

66 New York Times v Sullivan (1964) 376 US 254. In the Derbyshire case the House of Lords preferred to base their judgment on common law, including that of the United States, rather than Art 10 of the European Convention.

67 With regard to the compatibility of the Reynolds decision with Art 10, see the recent European Court decision in Bladet Tromso and Stensass v Norway (2000) 29 EHRR 125. See also, Wright J, Tort Law and Human Rights (Hart 2001), chapter 5 .

68 (1996) 22 EHRR 128.

69 X Ltd v Morgan Grampian [1991] AC 1.

70 (1996) 22 EHRR 128, at para 39. 
The domestic law fundamentally reflects this stance and provides against disclosure unless such is necessary in the interests of specifically named interests. $^{71}$ Notwithstanding this, a number of decisions of the domestic courts after the Goodwin judgment have allowed press sources to be disclosed on almost identical facts. ${ }^{72}$ The courts have attempted to explain such decisions on the basis that the facts in the particular case were distinguishable. For example, the Court of Appeal in Centaur distinguished the Goodwin case on the basis that in the present case the unknown source was still employed by the company. This, according to the Court of Appeal allowed the court at first instance to uphold the orders in spite of their consequences on the disclosure of press sources. However, in Goodwin, the European Court made specific provision for such a case, and safeguarded the disclosure of press sources despite such a possibility:

"Unless aware of the identity of the source, Tetra would not be in the position to stop such further dissemination of the contents of the plan. . . . It also had a legitimate reason as a commercial enterprise in unmasking a disloyal employee. . . who might have continuing access to its premises, in order to terminate his or her association with the company. These are undoubtedly relevant reasons." 73

Yet despite the recognition of the company's claims, the European Court upheld the importance of preserving press sources. The true import of the decision in Goodwin, including the principles it advocates, appear to be lost on the domestic courts in Centaur, who appear to find it difficult to put the rights of press freedom above commercial and other interests. ${ }^{74}$ In such cases it is submitted that unless the domestic courts adopt the true spirit of the Convention they will continue to be at odds with the decisions of the European Court. Indeed, there are signs from a recent Court of Appeal decision in this area that the courts are prepared to do this, and thus to give this aspect of press freedom an enhanced status. In John and others $\mathrm{v}$ Express Newspapers and others the High Court ${ }^{75}$ had ordered the disclosure of a journalist's source who had disclosed privileged information of a client of a Barrister's chambers to the journalist. This decision was overturned on appeal to the Court of Appeal $^{76}$ because it found that there had been

71 See s 10 Contempt of Court Act 1981. There was, therefore, no need to change this law following the Goodwin judgment.

72 See Camelot v Centaur Communications [1998] 1 All ER 251, and Michael O'Hara Books Ltd v Express Newspapers plc, The Times, March 6, 1998.

73 (1986) 22 EHRR 128, at paras 44-45. In John and others v Express Newspapers and others (below) the Court of Appeal rejected the argument that the incident might have created a sense of mistrust in the workplace as unlikely, Lord Woolf MR at $\mathrm{p} 266, \mathrm{~d}-\mathrm{e}$.

74 See Professor Smith, "The Press the Courts and the Constitution" in (1999) CLP 127, pp 130-137. See also the recent decision in Interbrew SA v Financial Times Ltd and another, The Times, January 4 2002, where Lightman J granted an order for the disclosure of a source that had disclosed deliberately misleading information about the claimant's business affairs. This decision was upheld by the Court of Appeal: The Times, March 21 2002. The House of Lords has refused leave to appeal, but the company did not insist on the source being revealed.

75 Reported in [2000] New Law Journal, 342.

76 John and others v Express Newspapers and others [2000] 3 All ER 257. 
insufficient efforts made to find the source of the information. According to Lord Woolf MR, the failure of the High Court to show a demonstrable public interest in ordering disclosure gave a disproportionate weighting to professional privilege and undervalued the interests of journalists. ${ }^{77}$

The government has not been defeated in all cases involving the balancing of such rights and interests. ${ }^{78}$ Nevertheless, as cases such as Sunday Times show, domestic law and enforcement agencies can often take an excessive or unsympathetic approach to this dilemma. ${ }^{79}$ The cases in this section highlight that the European Court has consistently found the United Kingdom government in violation of the Convention despite the domestic law's efforts to accommodate the right and to provide with necessary protection against unnecessary interferences. Doctrines such as proportionality will, no doubt, assist the courts in redressing this balance, but if the government's record in Strasbourg is to improve in this aspect, the courts and Parliament will need to take heed of the case law, and the principles it expounds. This, it is submitted, must be the case particularly vis $a$ vis cases involving excessive executive discretion and the tendency of the law to undermine the rights of minority and vulnerable groups, areas which will now be examined specifically.

\section{ii) Where the law and the courts allow too much administrative discretion}

There have been numerous cases where the European Court has found the United Kingdom to be in violation of the Convention because domestic law has given administrators a level of discretion incompatible with the provisions and ideals of the Convention. Related to this statutory empowerment is, of course, the refusal, or constitutional inability, of the courts to scrutinise such acts or decisions to an extent consistent with the principles of the Convention and its case law. ${ }^{80}$ This state of affairs,

77 Ibid, Lord Woolf MR, at p 266, c. Contrast the decision in Ashworth Hospital Authority v MGN Ltd [2001] 1 WLR 515 where the Court of Appeal ordered disclosure when confidential medical files had been leaked. The House of Lords dismissed an appeal, confirming that the situation was exceptional and thus justified disclosure: Ashworth Security Hospital v MGN Ltd, The Times, 1 July 2002, [2002] 1 WLR 2033.

78 In addition to the cases involving morality and free speech and the cases involving claims made by transsexuals (dealt with below), see, for example, Ahmed $\mathrm{v}$ United Kingdom (2000) 29 EHRR 1, where the European Court upheld the restrictions placed on certain local government officers holding political office. See also Buckley v United Kingdom (1997) 23 EHRR 101 and the more recent case of Chapman, Coster, Beard, Lee and Smith v United Kingdom (2001) 33 EHRR 18: rights of the community overrode gypsies' right to enjoy family and home life by living in a caravan on her land. See also $B$ and $P \vee$ United Kingdom, (The Times, May 15, 2001: denial of a public hearing and a public judgment in custody proceedings was not incompatible with arts 6 or 10 of the Convention.

79 This is further highlighted in two recent judgements regarding freedom of expression and the right of peaceful assembly: Steel v United Kingdom (1999) 28 EHRR 603 and Hashman and Harrap v United Kingdom (2000) 30 EHRR 241.

80 See in particular $R$ v Secretary of State for the Home Department Ex parte Brind [1991] AC 696, where the House of Lords held that the Convention could only be used in cases of statutory ambiguity, and not in cases where the width of executive 
exacerbated by the absence of a true separation of powers within the British Constitution, has led to the United Kingdom government being called to account before the European Court on a number of occasions.

The recent decision of the European Court in Lustig-Prean and Beckett ${ }^{81}$ provides a perfect illustration of the law's inability or reluctance to challenge decisions in cases where the rights of individuals have been compromised by official discretion. In that case the European Court not only concluded that the applicants' rights under Articles 8 and 14 of the Convention had been violated by the ban and the investigations, but also decided that the remedy of judicial review failed to provide an adequate remedy to the applicants as required by Article 13 of the Convention. ${ }^{82}$ In the Court' opinion, the judicial review proceedings failed to comply with Article 13:

". . . even assuming that the essential complaints of the applicants before this Court were before and considered by the domestic courts, the threshold at which the High Court and the Court of Appeal could find the Ministry of Defence policy irrational was placed so high that it effectively excluded any consideration by the domestic courts of the question whether the interference with the applicants' rights answered a pressing social need or was proportionate to the national security and public order aims perused, principles which lie at the heart of the Court's analysis of complaints under Article 8 of the Convention." 83

Among the more important and high profile cases in this category are those that involved the challenge by prisoners (and other persons in detention) of ministerial discretion relating to their release. ${ }^{84}$ The decisions in Weeks $\mathrm{v}$ United Kingdom ${ }^{85}$ and Thynne, Wilson and Gunnell $\mathrm{v}$ United Kingdom, ${ }^{86}$ that following the serving of a discretionary life sentence prisoner's tariff period his or her continued detention should be decided by a judicial body and should not be dependant on the administrative discretion of the Home Secretary, resulted in the modification of such discretionary powers via the passing of the Criminal Justice Act 1991.87 In Thynne Wilson and Gunnell,

discretion was at issue. The House of Lords also held that it was not appropriate to use the doctrine of proportionality in judicial review cases of this nature.

81 See $\mathrm{n} 1$ above.

82 Contrast Vilvarajah v United Kingdom (1991) 14 EHRR 248 and Soering v United Kingdom 11 (1989) EHRR 439, with Thynne Wilson and Gunnel v United Kingdom (1990) 13 EHRR 666 and $X$ v United Kingdom (1981) 4 EHRR 188.

83 Smith and Grady v United Kingdom, at para 138. The inadequacies of traditional review was highlighted by Lord Steyn in $R$ v Secretary of State for the Home Department, Ex parte Daly [2001] 2 WLR 1622, at 1635 B-1636 C, dealt with later in the article.

84 See G Richardson, "Discretionary life Sentences and the ECHR" [1991] PL 34 and E Fitzgerald, "The Criminal Justice Act 1991: Preventative Detention of the Dangerous Offender" [1995] EHRLR 39.

85 (1988) 10 EHRR 293.

86 (1990) 13 EHRR 666.

87 S 34 Criminal Justice Act 1991, now contained in s 29 of the Crime (Sentences) Act 1997. The position regarding mandatory life sentence prisoners was left intact, and had been upheld by the European Court: Wynne v United Kingdom (1994) 19 EHRR 333 and by the domestic courts: $R$ v Secretary of State for the Home 
relying on its previous decision in Weeks, the European Court stressed the importance of independent and judicial investigation into the legality of the applicants' continued detention:

". . . the factors of mental instability and dangerousness are susceptible to change over the passage of time and new issues of lawfulness may thus arise in the course of detention. It follows that at this phase in the execution of their sentences the applicants are entitled under Article 5(4) to take proceedings to have the lawfulness of their continued detention decided by a court at reasonable intervals and to have the lawfulness of redetention determined by a court." $" 88$

Accordingly, the Court concluded that neither the Parole Board nor judicial review proceedings satisfied Article 5(4) in this respect. ${ }^{89}$ Similar amending statutory provisions were necessary in response to the Court's decision in Hussain and Singh v United Kingdom ${ }^{90}$ in relation to the power of the Home Secretary to detain young persons at Her Majesty's Pleasure. ${ }^{91}$

Again, in the context of the detention of persons under mental health legislation, the case of $X \vee$ United Kingdom ${ }^{92}$ illustrates perfectly both the willingness of Parliament to bestow administrative discretion on government ministers and the court's resultant inability to control the exercise of such discretion. In this case, following a conditional discharge, the applicant had been recalled, by the Home Secretary, to Broadmoor Hospital under the section 66 of The Mental Health Act 1959. This order was made following complaints, made by his wife, regarding his recent behaviour. An application for judicial review, and habeas corpus proceedings, were unsuccessful. The applicant claimed a violation of Article 5 of the Convention. The European Court found there to be a basic violation of the right under Article 5 (4) of the Convention to challenge the legality of a person's detention, noting that the remedies of habeas corpus and judicial review failed to provide an adequate remedy in such circumstances. The Court held as follows:

"Article 5(4) . . does not embody a right to judicial control of such scope as to empower the court, on all aspects of the case, to substitute its own discretion for that of the decision-making authority. The review should, however, be wide enough to

Department, Ex parte Anderson and Taylor [2002] 2 WLR 1143. However, the ruling in Wynne was questioned in the recent European Court decision in Stafford v United Kingdom, The Times, 31 May 2002, where the European Court held that there was no longer a basis for distinguishing the sentences.

88 (1990) 13 EHRR 666, at para 76. See also Oldham v United Kingdom (2001) 31 EHRR 34 and Hirst v United Kingdom, The Times, August 32001 on the incompatibility of unreasonable delays between reviews with art 5(4) of the Convention of delays between reviews

$89 \mathrm{Ibid}$, at para 80.

90 (1996) 21 EHRR 1.

91 See now s 90 of the Powers of Criminal Courts (Sentencing) Act 2000. See also 60 Criminal Justice and Court Services Act 2000, which equates such detainees with discretionary life sentence prisoners.

92 (1981) 4 EHRR 235. 
bear on those conditions which, according to the Convention, are essential for the "lawful" detention of a person on the ground of unsoundness of mind. . This means that in the instant case Article 5(4) required an appropriate procedure allowing a court to examine whether the patient's disorder still persisted and whether the Home Secretary was entitled to think that a continuation of the compulsory confinement was necessary in the interests of public safety." 93

The European Court has also questioned the use of administrative discretion in the deportation and extradition cases discussed below ${ }^{94}$ and in Chahal v United Kingdom ${ }^{95}$ the Court was of the opinion that the inability of the applicant to question the findings of the Home Secretary in relation to his deportation constituted a violation of Article 5 of the Convention. For that reason, the Court took the unusual step of finding a violation of Article 13, which guarantees an effective remedy to anyone whose Convention rights have been infringed..$^{96}$

The above cases illustrate the inadequacy of a system of judicial review which is restricted to looking at the strict legality of administrative decisions and which makes too little allowance for cases which have a human rights context. ${ }^{97}$ Equally importantly, the cases show that the legal system is often prepared to put what should be independent and impartial judicial discretion into the hands of administrators and thus put the rights and liberty of individuals at the discretion of inappropriate personnel.

Even prior to the 1998 Act there were some signs that the courts were responding to the principles of the Convention and to the rulings of the European Court of Human Rights by taking a harder look at acts and decisions that interfere with human rights. The case of ex parte Saville ${ }^{98}$ provides an example. In that case a tribunal which had been set up to inquire into the Bloody Sunday shootings decided to take away the anonymity of several soldiers so as to provide a fairer and more open procedure. Both the High Court and the Court of Appeal quashed the decision, and the wording of the judgment in the Court of Appeal is revealing. In the Court's opinion the tribunal had failed to attach sufficient significance to the risk posed to the safety of the former soldiers. ${ }^{99}$ Furthermore, it felt that the tribunal had not been sufficiently aware that the denial of anonymity would affect the soldier's perception of the fairness of the inquiry. ${ }^{100}$ The Court concluded

93 At para 58. See also Johnson v United Kingdom (1999) 27 EHRR 296, but contrast Cottenham v United Kingdom (Application No. 36509/97).

94 Under the heading 'Where the Law Failed to Protect Vulnerable Sections of Society.'

95 (1997) 23 EHRR 413.

96 Following the decision in Chahal, Parliament passed the Special Immigration Appeals Commission Act 1997 which set up the Special Immigration Appeals Commission to hear appeals against deportation orders made by the Secretary of State.

97 See N Blake, "Judicial Review of Discretion in Human Rights Cases" [1997] EHRLR 391, pp 400-403.

$98 R \mathrm{v}$ Lord Saville of Newdigate, Ex parte A [1999] 4 All ER 860.

99 Ibid, per Lord Woolf, at $\mathrm{p} 882$, b.

100 Ibid, at pp 880, j-881, a. 
that anonymity for the soldiers would only have had a limited effect on the openness of the inquiry and thus the granting of anonymity was the only possible decision open to the tribunal. ${ }^{101}$

This case shows that the court was prepared to assess the reasonableness of the initial decision, and to overturn it if the court felt that it failed to give sufficient weight to a relevant human right. This level of review has been inconsistent within the established limits of judicial review, ${ }^{102}$ but, notwithstanding the margin of appreciation afforded to respondent Member States, is consistent with the legitimate role of the European Court of Human Rights. Accordingly, in the post Human Rights Act era the courts must be prepared to employ these doctrines in hard cases and to demand strong justification from decision-makers who have violated Convention rights. ${ }^{103}$ In order to comply with the European Convention, the judiciary need to abandon their previous deferential role and to be prepared to challenge the basis and proportionality of government action. Indeed, in the post-Human Rights era there is strong evidence that the courts are prepared to embrace their new role. ${ }^{104}$

To conclude this section, although the European Court does provide a generous margin of appreciation in many cases where the authorities have to resolve conflicting rights and interests, which has led to unpredictability in the case law of the European Court, the domestic courts will need to adapt a more consistently intense review of administrative decisions which impinge

101 Ibid, p 882, f-g. See also B v Secretary of State for the Home Department [2000] HRLR 439, where the Court of Appeal held that the deportation of someone who had been convicted of assaulting his children was, given the fact that he had lived in the United Kingdom for more than 35 years, disproportionate and thus contrary to both EC law and Art 8 of the European Convention. A similarly anxious scrutiny was applied by the Court of Appeal in $R$ (A and others) v Lord Saville of Newdigate and others, The Times, December 21, 2001, a post-Human Rights Act case, where it was held that the decision that soldiers give evidence for the inquiry in Northern Ireland should be quashed as being incompatible with art 2 of the Convention.

102 See in particular $R$ v Cambridge Area Health Authority Ex parte B [1995] 2 All ER 129, where the Court of Appeal made it clear that the court should not interfere with the weight given by a decision-maker to a particular relevant factor. Note that in that case the right to life was also at issue. Contrast the decision in $A$ (children) (conjoined twins; surgical separation), R) [2000] 4 All ER 961 where the court conducted an intensive review in relation to Art 2 of the Convention.

103 The role of the courts in post-Human Rights Act cases has been confirmed by the Court of Appeal in $R$ v Secretary of State for the Home Department, Ex parte Mahmood [2001] 1 WLR 840 and by the House of Lords in $R$ v Secretary of State for the Home Department, Ex parte Daly, [2001] 2 WLR 1622. See P Craig, "The Courts, the Human Rights Act and Judicial Review" (2001) 117 LQR 389, pp 395-397. For a critical account of the distinction between Wednesbury unreasonableness and proportionality, see M Elliot, "The Human Rights Act 1998 and the standard of Substantive Review" (2001) CLJ 301.

104 See in particular $R$ v Secretary of State for the Home Department, Ex parte Daly, $\mathrm{n} 129$ above, $R$ v Secretary of State for the Home Department, Ex parte Louis Farrakhan, unreported, decision of the Court of Appeal [2001] EWHC Admin 781, $R$ (A and another) v Lord Saville of Newdigate and others, The Times, December 21,2001, and $R$ (on the application of Samaroo) v Secretary of State for the Home Department, The Times, September 18, 2001. 
on Convention rights. ${ }^{105}$ Cases such as Smith and Grady and Chahal serve as perfect illustrations of the limits of traditional grounds of judicial review. Equally, cases such as Thynne, Wilson and Gunnell and Hussain and Singh illustrate the willingness of the Parliament and the public to bestow impartial judicial functions on the executive. In both areas, the European Court has ruled against the government in a variety of cases, and in the post Human Rights Act era both Parliament and the courts need to take these examples on board in reformulating their powers and duties.

\section{ii) Where the law failed to protect the rights of vulnerable sections of society}

It is hardly surprising that in a jurisdiction which does not have an enforceable bill of rights, and practices parliamentary sovereignty within its constitutional arrangements, that the rights and liberties of minority and vulnerable groups are neglected. Into this category fall groups such as prisoners and those under arrest or in detention, asyleees and deportees, sexual minorities and children. ${ }^{106}$ The rights of prisoners have benefited greatly from the intervention of the European Court. In Golder v United Kingdom ${ }^{107}$ the Court held that there had been a violation of Golder's rights under Articles 6 and 8 of the Convention when he had been refused the right to bring legal proceedings against a prison officer. Rejecting the government's contentions that the rights of prisoners, due to the fact of their incarceration, were subject to implied restrictions, the Court held that such a submission was not in keeping with Article 8 or the case law. The restrictive formulation used in Article 8 (2) - " there shall be no interference. . . except such as. . ." left no room for the concept of implied limitations. ${ }^{108}$ This case was followed by Silver v United Kingdom ${ }^{109}$ in which the Court held that a large number of restrictions relating to prisoners' correspondence were unlawful under the Convention as being either insufficiently accessible or clear to be prescribed by law, or so excessive as to be disproportionate. ${ }^{110}$ In the Courts' judgement any restrictions had to be based in law, adequately accessible and formulated with sufficient precision. In addition, in order for such restrictions to be necessary in a democratic society they must not be excessive. ${ }^{111}$

The cases of Golder and Silver were, therefore, instrumental in controlling arbitrary interference with prisoners' rights, and of alerting Parliament and

105 See S Fredman, "Judging Democracy: The Role of the Judiciary Under the Human Rights Act 1998" (2000) CLP 99. A warning against increased judicial interference in the area of, inter alia, human rights is given by JAG Griffiths: "The Brave New World Of Sir John Laws" (2000) 63 MLR 159.

106 See C Harvey and S Livingstone, "Protecting the Marginalised: The Role of the European Convention on Human Rights" (2000) 51 NILQ 445, discussing, in particular, the protection of prisoners, immigrants and asylum seekers under the European Convention.

107 (1975) 1 EHRR 524.

108 At para 44. The European Court did accept that the rights under Art 6 might be subject to implied limitations.

109 (1983) 5 EHRR 347.

110 The equivalent rules and regulations of the Scottish legislation were successfully challenged in Campbell v United Kingdom (1993) 15 EHRR 137.

111 At paras 85-88, and para 99. 
the courts of the unlawfulness of refusing to accommodate such rights Although not all cases brought in the area of prisoners' rights have been successful, ${ }^{112}$ the cases highlighted the fundamentally different attitudes of the European Court and the domestic authorities towards prisoners and the enjoyment of their human rights. ${ }^{113}$

The law and practice relating to the treatment of asylees and deportees has also given rise to a good deal of litigation involving the United Kingdom before the European Court and most cases have been decided in favour of the applicant. In Soering v United Kingdom ${ }^{114}$ it was held that the proposed deportation of a young German national to the United States to face a charge of murder and, possibly, the death penalty, was in violation of Article 3 of the Convention. The Court concluded that the applicant had been subjected to a real risk that he would face the degrading and inhuman conditions of death row. This was followed in Chahal v United Kingdom ${ }^{115}$ where it was held that the deportation of an Indian national who was likely to face persecution on his return was in violation of Articles 3 and 5 of the Convention. In relation to its determination under Article 3, the Court held that in cases such as the present the Court's examination of the existence of a real risk of ill-treatment must necessarily be a rigorous one, in view of the absolute character of Article 3 and the fact that it enshrines one of the fundamental values of the democratic societies making up the Council of Europe. ${ }^{116}$ Although the government has successfully defended some deportation and extradition cases, ${ }^{117}$ in general the cases suggest that interests of national security and general public interest are more important to government ministers and the supervisory domestic courts than the protection of the individual's fundamental human rights. ${ }^{118}$ This is borne out by the comments of the European Court in Chahal, where in concluding that there was a sufficient risk of ill treatment to the applicant, and finding that there was a breach of Article 13 of the Convention they observed:

". . . neither the advisory panel nor the courts could review the decision of the Home Secretary to deport Mr Chahal to India with reference solely to the question of risk, leaving aside national security considerations. On the contrary, the courts' approach was one of satisfying themselves that the Home

112 See, in particular, Boyle and Rice v United Kingdom (1988) 10 EHRR 425.

113 See S Livingstone, "Judicial Review in Prisons", in Hatfield (ed) Judicial Review: A Thematic Approach (1996)

114 (1989) 11 EHRR 439.

115 (1997) 23 EHRR 413

116 At para 96. After considering all the claims of the applicant, and the current political climate in India, at the time of the applicant's deportation proceedings, and after, the Court was of the opinion that, despite the assurances given by the Indian authorities, there was a real risk of the applicant being subjected to treatment contrary to Art 3 (para 107).

117 See Vilvarajah v United Kingdom (1991) 14 EHRR 248, Launder v United Kingdom (European Commission of Human Rights, [1998] European Human Rights Law Review, 337) and Singh v United Kingdom, admissibility decision of the European Court, September 262000.

118 See A Nicol, National Security and Free Speech [1996] EHRLR 37. See also the cases referred to in $n 48$ above. 
Secretary had balanced the risk to $\mathrm{Mr}$ Chahal against the danger to national security." 119

Sexual minorities - most notably homosexuals and transsexuals - have brought a host of cases against the United Kingdom government claiming that the law failed to safeguard their basic rights under the Convention. In Dudgeon v United Kingdom ${ }^{120}$ the European Court held that the applicant's right to private life had been violated by the existence of laws in Northern Ireland which prohibited sexual relations between homosexuals, irrespective of the age of the participants. ${ }^{121}$ In that case the European Court warned of the danger of suppressing individual rights by means of majority opinion based on intolerance. Referring to the government's contention that there was a substantial body of opinion opposed to a change in the law, the Court stressed that ". . . this cannot of itself be decisive as to the necessity for the interference with the applicant's private life. . it is for the Court to make the final evaluation as to whether the reasons it has found to be relevant were sufficient in the circumstances. . ."122 More recently the European Commission have held that domestic laws which distinguished between heterosexuals and homosexuals with regard to the age of sexual consent were contrary to article $8 .{ }^{123}$ The right of homosexuals to equal treatment and freedom from arbitrary treatment was also the subject of the litigation surrounding the ban on homosexuals in the armed force. ${ }^{124}$ In those cases the European Court found that the treatment of those individuals was justified on no greater basis than the intolerance of the views of the majority of serviceman, reiterating the unacceptability of such grounds for violating individual human rights. ${ }^{125}$

Cases involving transsexuals who claim that their treatment in domestic law is contrary to their Convention rights to private life and to marry have also been before the European Court on numerous occasions. ${ }^{126}$ Until very recently, all such challenges had been unsuccessful, but in Goodwin v United Kingdom and $I \mathrm{v}$ United Kingdom ${ }^{127}$ the European Court ruled that the government's margin of appreciation in this area a could no longer be used to justify the discriminatory treatment afforded to such persons. Although, to date, all such challenges have been unsuccessful, the number of cases is indicative of the treatment in domestic law of minority groups who are

119 At para 153.

120 (1981) 4 EHRR 149.

121 Ss 61 and 62 of the Offences Against the Persons Act 1861 and s 11 of the Criminal Law Amendment Act 1885.

122 At para 59.

123 Sutherland v United Kingdom, The Times, April 13 2001. The European Court of Human Rights struck the case out on 27 March, 2001 after the Sexual Offences (Amendment) Act 2000 was passed, equalising the age of sexual consent for heterosexuals and homosexuals.

124 Smith and Grady v United Kingdom and Lustig Prean and Beckett v United Kingdom, n 1 above.

125 Ibid, at paras 104-105, and 97-98 respectively.

126 See Rees v United Kingdom (1987) 9 EHRR 56; Cossey v United Kingdom (1990) 13 EHRR 622; $X, Y$ and Z v UK (1997) 24 EHRR 143; and Sheffield and Horsham v United Kingdom (1999) 27 EHRR 163.

127 The Times, 12 May 2002. 
vulnerable to the intolerance of public opinion, and whose rights are violated often on the basis of no more justification than administrative convenience. ${ }^{128}$

The rights of young persons are also vulnerable to the law and its practice, and in particular to the vagaries of public opinion, which feel that such persons are not worthy of the full protection of their civil liberties. The United Kingdom Government had been the respondent in several high profile cases involving judicial or other forms of corporal punishment, some finding that the applicants had been subjected to treatment which was degrading and thus contrary to Article 3. In Tyrer v United Kingdom ${ }^{129}$ the government was held accountable for the carrying out of birching in the Isle of Man. The Court held that the subjection of the applicant to corporal punishment was clearly contrary to Article 3. In that case the majority of the Court rejected arguments that such punishment was excusable on the basis that it acted as a deterrent and that it was not regarded as inhuman or degrading by the local community. ${ }^{130}$ Significantly the British judge, offering a dissenting judgement, refused to find that the practice was contrary to Article 3 on the ground that the treatment was meted out to a young person. ${ }^{131}$

More generally there have been complaints regarding corporal punishment in schools, which were defended by the government on the basis that the applicants, not being adults, had limited rights under the Convention. The European Court has not outlawed such punishment per se, provided the parents agree to such punishment and provided such punishment is not excessive in the circumstances, ${ }^{132}$ and eventually such punishment has been outlawed in both state and private sector schools. ${ }^{133}$ However, the recent case of $A \mathrm{v}$ United Kingdom ${ }^{134}$ illustrates that the government's insistence on compromising the rights of young persons may continue to be at odds with the views of the European Court and in violation of the rights of children under the Convention. In this case the Court held that the failure of the domestic law to provide adequate protection against excessive parental chastisement was in violation of Article 3 of the Convention, ${ }^{135}$ thus calling for specific law reform in this area and alerting the government to the fact that their attitude towards the rights of children in general may well be incompatible with the Convention. ${ }^{136}$

128 See, however, B v France (1992) 16 EHRRR, 1. Domestic law protects transsexuals from discrimination in employment: The Sex Discrimination (Gender Reassignment) Regulations 1999. In Elizabeth Anne Bellinger v Michael Jeffrey Bellinger and HM Attorney-General [2002] 2 WLR 411 it was held (Thorpe LJ dissenting) that it was not appropriate for the courts to depart from previous domestic and European Convention law, and that the matter should be resolved by Parliament. The House of Lords will hear the case in March 2003.

129 (1978) 2 EHRR 1.

130 Ibid, at para 31.

131 Dissenting Opinion of Judge Sir Gerald Fitzmaurice.

132 See Costello-Roberts v United Kingdom (1993) 19 EHRR 112.

133 See the Education (No 2) Act 1988. The School Standards and Framework Act 1998 has abolished corporal punishment in other schools.

134 (1999) 27 EHRR 611.

135 See also the European Court of Human Rights decision in $Z \mathrm{v}$ United Kingdom (n 39 above).

136 In $R$ v $H$ (Reasonable chastisement), The Times, May 17, 2001, it was held that for the purpose of the defence of parental chastisement, the jury should be 
The case of $A$ illustrates the requirement under the Convention to treat young persons not only without discrimination, but also, in certain situations, to provide them with added protection. ${ }^{137}$ Further evidence is provided by the ruling of the European Court in $T$ and $V \mathrm{v}$ United Kingdom ${ }^{138}$ where it was held that the applicants, two young boys found guilty of murdering a two year old, had their right to a fair trial violated. In this case it was held that the subjection of the boys to a high public profile, adult trial was in contravention of Article 6 of the European Convention. The European Court, in deciding whether there had been a violation, noted that Article 6(1) guarantees the right of an accused person to participate effectively in his criminal trial. ${ }^{139}$ It then considered whether procedures such as publicity, which in general were considered to safeguard the rights of adults on trial, should be abrogated in respect of children so as to promote their understanding and participation. The Court concluded that:

“. . . the formality and ritual of the Crown Court must at times have seemed incomprehensible and intimidating for a child of eleven, and there is evidence that certain of the modifications to the courtroom, in particular the raised dock which was designed to enable the defendants to see what was going on, had the effect of increasing the applicant's sense of discomfort during the trial, since he felt exposed to the scrutiny of the press and the public." 140

Cases such as Venables and Thompson and $A$ illustrate the fine line that governments must tread in the protection of children's rights. ${ }^{141}$ They also typify the government's vulnerability to claims brought by groups who have no or little political voice and whose rights as a consequence are often neglected or given insufficient weight by the government and the law, often with the acquiescence and positive approval of public opinion. The courts can expect a flood of challenges from such groups under the Human Rights Act and cases from the European Court involving prisoners, asylees and deportees, children and sexual minorities provide ample evidence of the

directed on the factors identified in A $\mathrm{v}$ United Kingdom as to whether the punishment was contrary to Art 3 of the Convention.

137 See Opromolla, "Children's rights under art 3 and 8 of the European Convention on Human Rights: recent case law" (2001) ELR HR/42.

138 (2000) 30 EHRR 121.

139 On the question of the trial and detention of young offenders and the European Convention, see Kilkelly, "The Human Rights Act 1998: Implications for the Detention and Trial of Young Offenders" (2000) 53 NILQ 446.

$140 T$ v United Kingdom at para 86. See now the Lord Chief Justice's Practice Direction (Crown Court: Trial of Children and Young Persons), The Times, 17 February 2000 which gives guidance on the arrangements for the trial of young defendants. On 26 October 2000 Lord Woolf CJ announced a tariff period of 8 years for both Venables and Thompson, following a practice statement made on 27 July, 2000: [2000] 4 All ER 831, which has now been amended by the Lord Chief Justices Opractice Statement: life sentences, The Times, 4 June 2002. [2002] All ER***.

141 See Haydon and Scraton, "Condemn a Little More, Understand a Little Less': The Political Context and Rights Implications of the Domestic and European Rulings in the Venables-Thompson Case" (2000) 27(3) JLS 416. 
law's past intolerance of such groups, and of the unacceptable interference with their Convention rights.

\section{THE HUMAN RIGHTS ACT 1998}

It is not my intention to look at the provisions of the Human Rights Act 1998 in any detail. ${ }^{142}$ In particular the constitutional difficulties involved in the courts' ability to issue a declaration of incompatibility, ${ }^{143}$ and the procedures whereby relevant Ministers can rectify or endorse such legislation have already been the source of intense and voluminous academic coverage..$^{144}$ Rather, I intend to look at some central provisions of the Act, and, in passing, at the post-Act case law, to identify whether the Act's implementation is capable of redressing the deficiencies of the traditional system of rights protection that have been highlighted by the European Court.

Of particular relevance are sections 2, 3 and 4 of the Act, which provide the courts with the power to interpret and develop domestic law in the light of the European Convention and its case law and, in exceptional cases, to declare legislative provisions incompatible with the Convention. Again, much has been written on this subject, ${ }^{145}$ but this part of the article shall concentrate on the potential impact of these sections on the development of suitably compatible human rights jurisprudence in domestic law. In particular, I will address the question of whether the 'incorporation' of the Convention via the 1998 Act is capable of redressing the problems that have been highlighted in this article and which have so marred the United Kingdom's record of human rights protection under the Convention over the last thirty years.

Section 2 of the Act provides that a court or tribunal must take into account the case law of, inter alia, the European Court of Human Rights when determining questions which arise in connection with a Convention right. Although, as we have seen, the Convention has played some part in the development of domestic human rights law, the courts have not always allowed themselves to refer to the specific case law of the Convention in

142 For a comprehensive account of the Act and its implications see R Clayton and $\mathrm{H}$ Tomlinson, Law of Human Rights (2000); S Grosz and J Beatson, Human Rights: the 1998 Act and the European Convention (2000) and J Coppel, The Human Rights Act 1998: enforcing the European Convention on Human Rights in domestic law (1999).

143 Under s4 of the Human Rights Act 1988

144 See, for example, D Feldman, "The Human Rights Act 1998 and constitutional principles" (1999) LS 165, and N Bamforth, "The Human Rights Act 1998 and Parliamentary Sovereignty" [1998] PL 572.

145 See in particular M Beloff, "What does it all mean? Interpreting the Human Rights Act 1998" in L Betten (ed) The Human Rights Act 1998 - What it Means (1999), chapter 1; A Lester, "The Art of the Possible [1998] EHRLR 665; Hooper "The Impact of the Human Rights Act on Judicial Decision-making [1998] EHRLR 676; Lord Irvine, "The Development of Human Rights in Britain under an incorporated Convention on Human Rights" [1998] PL 221; Martens, "Incorporating the European Convention: The Role of the Judiciary [1998] EHRLR 5; H Wade, "The Human Rights Act and the Judiciary" [1998] EHRLR 520. 
determining cases under domestic law. ${ }^{146}$ Section 2 of the Act allows the domestic courts to have full access to the case law, and, more importantly, to the principles of human rights protection advocated by the European Court, including the previously forbidden doctrine of proportionality. ${ }^{147}$ This should intensify the review of administrative (and, within the boundaries of the Human Rights Act, legislative) interferences with human rights, subjecting such interferences to scrutiny consistent with that of the European Court. The distinction between proportionality and the traditional grounds of review was highlighted by Lord Steyn in $R \mathrm{v}$ Secretary of State for the Home Department, ex parte Daly. ${ }^{148}$ His Lordship first noted that proportionality required the reviewing court to assess the balance that the decision maker had struck, not merely whether the decision was within the range of reasonable decisions. Secondly, proportionality required attention to be directed to the relative weight accorded to the interests and considerations. Thirdly, his Lordship noted that the decision of the European Court of Human Rights in Smith and Grady v United Kingdom clearly showed that even the heightened scrutiny test developed by the domestic courts was not necessarily appropriate to the protection of human rights because it failed to address the question of whether the interference met a pressing social need and was proportionate to the legitimate aim being pursued. ${ }^{149}$ Significantly, his Lordship felt that the test applied by Lord Phillips MR in ex parte Mahmood, ${ }^{150}$ whether a decision-maker could reasonably have concluded that the interference was necessary to achieve one or more of the legitimate aims recognised by the Convention was insufficiently intense to comply with the jurisprudence of the European Court. ${ }^{151}$

There are indeed signs that the courts are prepared to use these new powers and to subject administrative acts to intense scrutiny in order to assess their

146 See the cases referred to in $\mathrm{n} 15$ and $\mathrm{n} \mathrm{16}$, above. The limited effect of Convention decisions was confirmed by the Court of Appeal recently in $R$ v Lyons and others, The Times, February 1, 2002.

147 See P Mahoney, "Principles of Judicial Review as Developed by the European Court of Human Rights: Their Relevance in a National Context," in Betten, The Human Rights Act 1998 - What it means (1999), chapter 3. See also P Craig, "The Courts, the Human Rights Act 1998 and Judicial Review (2001) 117 LQR 389.

148 [2001] 2 WLR 1622.

149 Ibid, at 1635D-1636A. See M Elliot, "The Human Rights Act 1998 and the Standard of Substantive Review" (2001) CLJ, 301.

${ }^{150} R$ v Secretary of State for the Home Department, ex parte Mahmood [2001] 1 WLR 840, at 857. The Master of the Rolls was indicating the appropriate test of review once the Act came into operation. For a critical account of this case see $\mathrm{R}$ Clayton, "Regaining a Sense of Proportion: The Human Rights Act and the Proportionality Principle" [2001] EHRLR 504. See also N Blake, "Importing Proportionality: Clarification or Confusion" [2002] EHRLR 19, R Clayton, "Developing Principles for Human Rights" [2002] EHRLR 175, 185-188, and Leigh, "Taking Rights Proportionately: Judicial Review, the Human Rights Act and Strasbourg" [2002] PL 265.

151 For a clear application of the Daly principle, see $R$ (on the application of Hirst) $\mathrm{v}$ Secretary of State for the Home Department, The Times, April 10 2002, where a blanket policy on prisoners contacting the media was successfully challenged. 
compatibility with an individual's Convention rights. ${ }^{152}$ In particular, in a number of cases involving freedom of expression, the courts have been prepared to question any interference that they regard as unnecessary and disproportionate. ${ }^{153}$ More specifically, there is evidence that the courts are prepared to scrutinise cases that might previously be regarded as nonjusticiable. For example in $R$ v Secretary of State for the Home Department, ex parte Farrakhan, ${ }^{154}$ the Administrative Court quashed the Home Secretary's order prohibiting the claimant from entering the country, finding that such an order constituted a disproportionate interference with the claimant's rights under article 10 of the European Convention. In the court's opinion, although the Home Secretary was to be afforded a wide margin of appreciation in deciding whether to continue the exclusion order, that did not mean that the court was inhibited from embarking upon a review of the reasons provided and the underlying circumstances in order to determine whether he had come to a conclusion that was open to a reasonable decision maker. This decision represents a radical departure from the traditional approach taken by the courts in this area, ${ }^{155}$ and, hopefully, is evidence of the courts' acceptance of the universal application of rights' protection granted under the European Convention. ${ }^{156}$

Of course, although the courts will have to take account of the case law, there will be no compulsion to follow it. ${ }^{157}$ Thus courts may wish to ignore a particular ruling of the Court, and, of course, will be bound to do so if the domestic law cannot be read in the light of the Convention. ${ }^{158}$ In addition, the courts may refuse to apply a particular case that they have taken into account, for the purpose of giving a more restrictive, or more generous, interpretation of the Convention and its rights. Evidence from the post-Act case law suggests that the courts are keen to follow the case law of the European Convention and are reluctant to take the Convention rights beyond

152 See for example $R$ ( $A$ and others) v Lord Saville of Newdigate and others, supra $\mathrm{n}$ 103. See also $R$ v Secretary of State for the Home Department, ex parte $P$ and $Q$ [2001] 1 WLR 2002, where the Court of Appeal held that the Prison Service's mother and baby policy was a disproportionate interference with the claimant's right to family life.

153 See, in particular $R$ v Secretary of State for Health, ex parte Wagstaff [2001] 1 WLR 292 and Attorney General v Punch and another [2001] 2 All ER 655. See also the Court of Appeal decisions in A v B plc and another, The Times, March 13 2002 and $R$ (on the application of ProLife Alliance) $v$ British Broadcasting Standards Corporation [2002] 2 All ER 756.

154 The Daily Telegraph, October 9, 2001.

155 See the cases dealt with in $\mathrm{n} 48$ above.

156 The decision of the High Court was overturned on appeal, decision of the Court of Appeal 30 April 2002, [2002] 3 WLR 481, although the Court accepted that the Home Secretary was subject to the doctrine of proportionality, albeit circumscribed by a wide margin of appreciation on behalf of the Secretary.

157 See J Wadham and H Mountfield, The Human Rights Act 1998 (1999), pp 30-33, and Klug, "The Human Rights Act 1998, Pepper v Hart and All That" [1999] PL 246, pp 250-252. Klug points out that this provision will also allow the courts to consider the jurisprudence under other international instruments.

158 S 3(1) Human Rights Act 1998. This is re-iterated in s 6 (2) (a) and (b) of the Act, which precludes a court granting a victim a remedy if such would be incompatible with clear primary or secondary legislation. 
such decisions. ${ }^{159}$ This restrictive approach, although legitimate, may, of course, result in further challenges under the Convention by applicants hoping that the European Court will adopt a more liberal approach to the relevant Convention right. Consequently, the domestic courts will need to be aware of the dynamic nature of the Convention and the flexibility of the Court's attitude to precedent.

In addition, two possible judicial tactics may be employed giving rise to concern. The first is that although the courts will refer to the case law of the Convention, they will fail to appreciate the true import of the case and the principles it is expounding. As explained above, there have been many cases where the domestic courts have ostensibly applied human rights concepts to the resolution of disputes, yet still failed to appreciate the significance of the human rights issue. This, accordingly, has led to the domestic court's ruling being out of line with subsequent decisions of the European Court. ${ }^{160}$ Secondly, the courts may be very tempted to restrict their jurisdiction, and in particular their power to interfere with administrative discretion, by relying on the doctrine of the margin of appreciation which has been employed by the European Court to temper their interference of the domestic laws and practices of the Member States. ${ }^{161}$ Although it has been argued that the doctrine, being one of international law, should not play a part in domestic law, ${ }^{162}$ it will be tempting for many judges to use the caution of the doctrine of Wednesbury Unreasonableness ${ }^{163}$ via the employment of the doctrine of the margin of appreciation whilst exercising their jurisdiction under the 1998 Act. Indeed, in the House of Lords' judgment in ex parte Kebeline, Lord Hope, whilst stating that the doctrine was not available to domestic courts as

159 See for example the Court of Appeal decision in Bellinger v Bellinger, supra $\mathrm{n} 128$, upholding the refusal of domestic law to recognise a marriage between a man and a male to female transsexual. In fact, in $R \mathrm{v}$ Secretary of Stat for the Home Department, ex parte Anderson and Taylor [2002] 2 WLR 1143, the Court of Appeal suggested that it would not be appropriate for the domestic courts to go against consistent rulings of the European Court of Human Rights, particularly when cases of a similar nature were pending before the European Court.

160 See, for example, the difference between the respective judgments of the domestic courts and the European Court of Human Rights in the area of free speech and contempt of court: contra Attorney General v Times Newspapers [1974] AC 273, with Sunday Times v United Kingdom (1979) 2 EHRR 245. Also contrast the decision of the European Court in the case of Goodwin v United Kingdom (1996) 22 EHRR 128, not only with the House of Lords decision in $X$ Ltd v Morgan Grampian [1991] AC 1, which led to the journalist talking the case to the Convention, but also the case law subsequent to the Goodwin judgment: Camelot v Centaur Communications [1998] 1 All ER 251.

161 See Handyside v United Kingdom (1976) 1 EHRR 737. For a detailed discussion on the doctrine of the margin of appreciation see Yourow, The Margin of Appreciation in the Dynamics of the European Human Rights Jurisprudence (Martinus Nijhoff 1997). See also H Lavender, "The Problem of the Margin of Appreciation [1997] EHRLR 360, and H Jones, "The Devaluation of Human Rights" [1995] PL 430.

162 See R Singh, M Hunt and Demitrou, "Is there a Role for the "Margin of Appreciation" in National Law after the Human Rights Act?" [1999] EHRLR 15

163 Associated Provincial Picture House Ltd v Wednesbury Corporation [1948] 1 KB 223. 
such, recognised that the questions that the courts had to decide under the Human Rights Act would involve a balance between competing interests:

"In some circumstances it will be appropriate for the courts to recognise that there is an area of judgment within which the judiciary will defer, on democratic grounds, to the considered opinion of the elected body or person whose act or decision is said to be incompatible with the Convention ..."164

Given the historical reluctance of the courts to interfere in executive decision-making, particularly in matters of political sensitivity as evidenced in cases such as Brind and Smith, and the cases on national security, there is understandable concern that the courts will be unwilling to adopt a consistent hands on approach in its review of decisions impacting on human rights. As we saw in those cases, not only did the courts refuse to sanction a European approach to the resolution of such disputes, they were also adamant that the decisions in question would have stood the tests laid down in international human rights instruments. This attitude may be strengthened by judicial views that even the European Court give a large area of latitude to member states and their law enforcement agencies, and consequently the courts may develop their own doctrine of the margin of appreciation in a desire to reduce the effect of human rights protection. ${ }^{165}$

Section 3 of the Act on the other hand obliges the courts to interpret domestic statues, wherever possible, in the light of the European Convention. As we have seen the courts, where they have a mind to at least, are capable of interpreting most legislative provisions in the light of constitutional principles and thus avoiding the unpalatable conclusion that Parliament intended to interfere with basic rights. ${ }^{166}$ This practice was continued after the Act in $R$ v Offen and others ${ }^{167}$ where the Court of Appeal used its powers under the Human Rights Act 1998 to interpret the controversial section 2 of the Crime (Sentences) Act 1997, which imposes a duty on the courts to grant a life sentence on defendants who have committed two serious offences, unless there were exceptional circumstances. In the Court of Appeal's judgment, if an offender did not constitute a significant risk to the public then that would be an exceptional circumstance which would justify the court in not imposing an automatic life sentence. The judgment was, therefore, based not only on the interpretation of the Act and Parliament's purposes in passing it, but also on the finding that such an interpretation would be compatible with the European Convention on Human Rights. ${ }^{168}$ A more

${ }^{164} R$ v DPP, Ex parte Kebilene [1999] 4 All ER 801, Lord Hope at $\mathrm{p} 844$.

165 In $R$ v Secretary of State for the Home Department, ex parte Farrakhan, The Times, 6 May 2002, [2002] 3 WLR 481, the Court of Appeal held that the margin of appreciation accorded to a decision-maker was all important, for it was only by recognizing the margin of discretion that the court avoided substituting its own decision for that of the decision-maker. In that case the Court of Appeal held that there were very good reasons to accord a particularly wide margin of discretion to the Secretary of State when making a decision on the exclusion of a person from the country on the grounds of national security.

166 See, for example, Waddington v Miah [1974] 2 All ER 377.

167 [2001] 2 All ER 154. 
radical approach to interpretation was evident in the House of Lords' judgment in $R$ v $A$ (Sexual Offence: Complainant's Sexual History. ${ }^{169}$ In that case it was suggested that the traditional approach to statutory interpretation should be abandoned if the wording was not capable of rendering a result consistent with Convention rights. ${ }^{170}$ There will, therefore, be plenty of opportunity for innovation. ${ }^{171}$

The power of the courts under section 4 of the Act to declare inconsistent legislation incompatible with the Convention provides the courts with an opportunity to expose the inconsistency of domestic law with the principles and case law of the Convention. This power will only be used if the courts are unable to interpret domestic legislation as being compatible with the Convention and the House of Lords has suggested that the power should be used sparingly and as a last resort. ${ }^{172}$ Thus far very few provisions have been declared incompatible and the courts appear to be adopting a cautious approach, particularly where the provision in question appears to be consistent with the case law of the European Convention itself, ${ }^{173}$ or where such a declaration would undermine legislation passed by a democratically elected Parliament. ${ }^{174}$ As with the some of the cases under section 3 of the

168 According to Lord Woolf CJ an alternative interpretation would lead to the sentence being arbitrary and disproportionate and thus in violation of Art 5, and possibly Art 3 of the European Convention. See also the decision of the House of Lords in $R$ v A (Sexual Offence: Complainant's Sexual History) [2001] 3 All ER 1 on the interpretation of s41 of the Youth Justice and Criminal Evidence Act 1999.

169 [2001] 3 All ER 1.

170 The House of Lords took a more cautious approach in $\operatorname{Re} S$; Re W [2002] 2 WLR 720 , where it was held that it was impermissible to use s3 avoid the clear words and policy of legislation passed by Parliament

171 See Young, "Judicial Sovereignty and the Human Rights Act 1998" (2002) CLJ 53.

$172 R$ v A, supra $\mathrm{n} 166$.

173 See $R$ v Secretary of State for the Environment, Transport and Regions, Ex parte Holding and Barnes [2001] 2 WLR 1389, where it was held that the Secretary of State's power to call in planning applications was not in violation of art 6 . See also the decision of the Court of Appeal in Wilson v First County Trust [2001] 3 All ER 229, that s 127(3) of the Consumer Credit Act 1974 was incompatible with both Art 1 of Protocol 1 and Art 6 of the Convention. See also $R$ v Mental Health Review Tribunal, Ex parte H, [2001] 3 WLR 512 However, in $R$ v Secretary of State for the Home Department, Ex parte Martinez and Pearson; Hirst v Attorney-General (The Times, 5 April 2001) the High Court held that s3 of the Representation of the Peoples Act 1983, which bars convicted prisoners from voting, was not incompatible with Art 3 of the First Protocol of the European Convention. Also, in R v Shayler [2002] 2 WLR 754, the House of Lords held that ss 1 and 4 of the Official Secrets Act 1989 were not incompatible with art 10 of the European Convention in not providing a public interest defence. For an overview of the impact of the Act in the first year, see J Wadham, "The Human Rights Act 1998: one year on" [2001] EHRLR 620.

174 See in particular Hirst v Attorney-General and $R$ v Shayler, supra $\mathrm{n} 170$ and $R \mathrm{v}$ $D P P$, ex parte Pretty [2001] 3 WLR 1598, where the House of Lords refused to declare s 2(1) of the Suicide Act 1961, which makes it unlawful to assist a person's suicide, incompatible with arts 2,3, 8 or 9 of the Convention. See now Pretty v United Kingdom (2002) 35 EHRR 1. The European Court declared the 
Act, many of these decisions will be challenged afresh before the European Court of Human Rights and time will tell as to whether the domestic courts are taking too restrictive approach to the Convention and whether they are paying undue deference to parliamentary sovereignty.

Thus, it is in the application of the law, and the consequent balancing of human rights with other interests that will pose the greatest challenge to the domestic courts. In the post-Act era, although there is evidence that the courts are more prepared to interfere with administrative decisions that interfere with fundamental rights, a very wide margin of appreciation appears to be given to legislative decisions passed by Parliament. In most cases this reticence to override legislation passed by a democratic body will be supported by the European Court, but in other cases the courts will need to rid themselves of an inherent reluctance to interfere with decisions that, although taken legally and for good reason, are disproportionate in the circumstances. For this to happen, the courts not only have to be aware of the case law of the Convention, but also need to examine the jurisprudence of the European Court in detail.

Finally, one area that appears to have been addressed by the courts in the post-Act era is the development of a common law of privacy. As noted above, the absence of a legal right to private life had led to a number of unfavourable rulings from the European Court of Human Rights. Under the Human Rights Act, the courts have assumed their responsibilities as a public body under section 6 and have developed the common law in such a way as to accommodate the right to private life as recognised in article 8 of the Convention. ${ }^{175}$ The courts have also recognised their duty under section 12(4) of the Act to take into account relevant privacy codes in deciding whether to interfere with freedom of expression and will thus need to employ the doctrine of proportionality to resolve such dilemmas. ${ }^{176}$ In this respect, the courts will need to take heed of the relevant Convention case law and to ensure that the correct balance is maintained. In addition, the courts will need to be careful that previous attitudes on the application of Convention rights to certain groups, such as prisoners, do not obstruct the protection of this particular right. ${ }^{177}$

case admissible, yet found there to be no violation of articles 2, 3, 8, 9 or 14 of the convention.

175 See Douglas and others v Hello! Ltd [2001] 2 WLR 992 and Venables and Thompson v News Group Newspapers Ltd and others [2001] 1 All ER 908. See R Singh and Strachan, "The Right to Privacy in English Law" [2002] EHRLR 129. However, in Secretary of State for the Home Department v Wainwright, The Times, January 4 2001, the Court of Appeal held that the Act could not have retrospective effect and confirmed that before the Act there was no common law right of private life.

176 See, in particular Venables and Thompson, supra 174 and $A \vee B$ plc, The Times, [2002] 2 All ER 545.

177 Contrast $R$ v Secretary of State for the Home Department, ex parte $P$ and $Q$, [2002] 1 WLR 2002, where the Court of Appeal held that a Prison Service Policy on babies in prison was inflexible and constituted an unjustifiable interference with the prisoners' right to family life under art 8 of the European Convention, with $R$ v Secretary of State for the Home Department, Ex parte Mellor [2001] 3 WLR 533, where the court rejected a submission that the prisoner had the right to artificially inseminate his wife. 


\section{CONCLUSIONS}

Through a study of the relevant case law, it is submitted that several conclusions may be drawn relating to the traditional arrangements for protecting human rights, the United Kingdom government's record before the European Court of Human Rights and the impact that the Human Rights Act 1998 may have in these areas.

On a general level, the traditional constitutional and legal arrangements for protecting human rights could be said to have provided, at best, a system that was a genuine but inconsistent attempt to protect fundamental rights. The cases dealt with under the first broad category, in particular cases such as Malone and Smith and Grady, revealed the danger of attempting to resolve human rights claims by the application of strict legal doctrines. In addition, the lack of a general bill of rights in domestic law led to many cases where the fundamental rights of individuals, such as prisoners, were exempted from legal protection. More specifically, the constitutional restraints placed on the judiciary have resulted in many cases where the domestic courts were unable, or unwilling to attach sufficient significance and weight to the human rights issue involved in the case. Thus in cases such as Sunday Times v United Kingdom and Observer and Guardian v United Kingdom, the European Court in finding a violation of the Convention, was critical of the approach taken by the domestic courts in attempting to balance human rights with other competing interests. Although there were signs that the judiciary were beginning to attach greater significance to matters such as freedom of the press, ${ }^{178}$ and to embrace the doctrine of proportionality, ${ }^{179}$ cases such as Brind not only stood for the rejection of proportionality, but illustrated perfectly the court's failure to appreciate the true import of the doctrine and the role that it given to them as protectors of human rights. At worst, however, the system left the individual vulnerable not only to the doctrine of parliamentary sovereignty, but also to the inconsistency and inadequacy of judicial activism ${ }^{180}$ and to the threat of majority public opinion. ${ }^{181}$ Although the case law of the Convention involving the United Kingdom covers a multitude of human rights violations, most of the defeats in Strasbourg can be related to our constitutional characteristics and to the nature and outcome of our system of rights protection: the failure to recognise certain human rights; the law's insistence on applying legal rules rather than concentrating on human rights principles; an absence of a uniform and principled approach to challenging official action; and the inevitable exclusion or restriction of minority rights or interests.

The case law also clearly illustrates the lack an effective domestic 'filtering' system for dealing with human rights disputes at the domestic level. Had

178 See, for example, the House of Lords' decisions in Reynolds and Turkington, n 68 above.

179 See, for example the Court of Appeal decision in $R \vee$ Lord Saville of Newdigate, Ex parte A, n 121 above.

180 As evidenced by cases such as Smith and Grady, as well as in the cases involving asylees and deportees and the numerous cases on free speech and freedom of the press.

181 In particular cases such as $V$ and $T$, and the cases on prisoners and sexual minorities. 
domestic law possessed a constitutional mechanism to deal with human rights cases then the European Court would not have been required to pronounce upon the compatibility of our law with the Convention on so many occasions. For those seeking to justify our record before the European Court, this argument would explain the number of appearances before the Court. It would not, however, explain the success rate of claims brought against the government. If the domestic arrangements are sound then although in the absence of a domestic constitutional court cases will be tested in the formal arena of Strasbourg, the majority of those cases should be defended successfully. The evidence, especially in the areas under the headings studied above, does not support this and it is clear that in certain areas the government and the domestic system is continually open to challenge as being incompatible with the Convention and other instruments of international human rights law. Again, the doctrine of Parliamentary Sovereignty, the absence of a bill of rights, the limited ability and willingness of the judiciary to embrace the full panalopy of principles of human rights protection, the over reliance on administrative discretion and the willingness to subject minority rights to the will of the majority all combine to leave human rights inadequately protected in the United Kingdom

And thus to the Human Rights Act 1998 and the future. As we have seen, domestic law had already accepted much of the Convention and its jurisprudence. Indeed, in certain areas domestic law and judicial decisions had gone beyond the Convention and provided a protection greater than available under the Convention. ${ }^{182}$ For example, in cases such as ex parte Venables and Thompson 183 in the House of Lords went further than the decision of the European Court in Hussain and Singh, although not as far as the decision of the European Court in $V$ and $T \mathrm{v}$ United Kingdom, and there are constant judicial and political calls to rectify the anomaly of the mandatory life sentence despite such a system passing muster with the European Court. ${ }^{184}$ The developments in the law of freedom of assembly provide another example of judicial activism, which appears to go further

182 For example, in $R$ v Secretary of State for the Home Department Ex parte Anderson [1984] QB 778, the Court of Appeal found the 'simultaneous ventilation' rule (restricting the right of prisoners to take civil actions until they had lodged an internal grievance) to be ultra vires the Prison Act 1952, despite the European Court Of Human Rights appearing to uphold its validity in Silver v United Kingdom (1983) 5 EHRR 347.

${ }^{183} R \mathrm{v}$ Secretary of State for the Home Department, ex parte Venables and Thompson [1998] 3 All ER 97.

184 The domestic courts have held that the Home Secretary's powers to set tariffs in the case of mandatory life sentence prisoners is both lawful and compatible with the European Convention: $R$ v Secretary of State for the Home Department, ex parte Anderson and Taylor [2002] 2 WLR 1143, leave to appeal to the House of Lords granted. The European Court appear to have resolved the dilemma by assimilating mandatory sentences with those of other life sentences: Stafford v United Kingdom, The Times, 31 May, 2002. See also $R$ v Secretary of State for the Home Department, Ex parte Lichniak and Pyrah [2001] 4 All ER 934, where it was held that automatic mandatory life sentences did not violate either art 3 or 5 of the Convention, although leave to appeal to the House of Lords has been granted. 
than is advocated by the text and case law of the Convention. ${ }^{185}$ These developments are, of course, to be welcomed, and should not be discouraged merely because the purpose of the 1998 Act is to bring the Convention home. The Act itself does not forbid the greater protection of human rights at the domestic level, and the Act should merely ensure that the minimum requirements of the Convention are met in English law. ${ }^{186}$ More specifically, it is hoped that the margin of appreciation, which has been adopted by the European Court to give deference to Member States in relation to the Court's supervision of alleged human rights violations, should not play an overly influential role in domestic law, either directly or indirectly.

Notwithstanding the development of a human rights jurisprudence in domestic law before the Human Rights Act 1998, it was clear that a number of laws and practices were in violation of the European Convention. Equally the judiciary showed a reluctance to interfere in certain areas and with certain decisions, and it is by no means certain that judges, armed with the doctrine of proportionality and other human rights norms, will be any more generous to certain human rights than they have in the past. In such cases both Parliament and the courts may be prepared to retain the status quo and wait and see what the European Court has to say on the matter, rather than adopting a brave, interventionist approach. There remains the fear, therefore, that rights that have attracted parliamentary and judicial support will continue to be safeguarded, within, and possibly beyond, that required by international law. On the other hand, those rights which are felt to come at too great a cost will continue to be inadequately safeguarded, particularly if there are any signs that the European Court might offer the government any latitude in such areas.

What the Act should bring is a more consistent and coherent system of human rights protection, leading to the development of human rights previously unrecognised in domestic law and a reasonably consistent application of human rights law to human rights disputes. ${ }^{187}$ For this to happen, however, it is not sufficient merely to free the judges from their existing constitutional and legal chains, and to equip them with the tools of European and international human rights law. For the Act to succeed in practice all departments of government, including the judges, have to fully

185 One notable example is in the law of trespassory assemblies, where the domestic courts have been prepared to interfere in the exercise of police powers in controlling demonstrations which the European Commission refused to find in violation of Arts 10 and 11 of the Convention: contrast DPP v Jones [1999] 2 All ER 257, with Pendragon v United Kingdom (Application No 31416/96). The recent case of DPP v Redmond-Bate (The Times, July 28, 1999) also appears to go further than both the judgment of the European Court in Steel v United Kingdom (1999) 28 EHRR 603 and the cautious approach of the Convention machinery in the general area of demonstrations and the law.

186 The Court of Appeal has held that a company could claim for breach of privacy, despite accepting the argument that Art 8 of the European Convention on Human Rights did not extend protection to such bodies: $R \mathrm{v}$ British Standards Commission, Ex parte British Broadcasting Corporation (Liberty intervening) [2000] 3 All ER 989.

187 For a critical analysis as to the extent that this has been achieved in the post-Act era, see R Clayton, "Developing Principles for Human Rights" [2002] EHRLR 175. 
understand and appreciate those 'European' principles and the general principles of human rights protection. ${ }^{188}$ In this respect an analysis of the case law of the European Court of Human Rights, particularly in those cases involving the United Kingdom, will be essential if the purpose of the Act is to be achieved in domestic law.

188 See Clements and Young, "Human Rights: Changing the Culture; Campbell, Human Rights: A Culture of Controversy"; M Hunt, "The Human Rights Act and Legal Culture: The Judiciary and the Legal Profession; and Young, The Politics of the Human Rights Act", all in (1999) 26 JLS. See also Adjei, "Human Rights Theory and the Human Rights Debate" (1995) $58 M L R$, and J Jowell and J Cooper (eds), Understanding Human Rights Principles (2001). 